\title{
Meningococcal infection
}

\begin{abstract}
-a review based upon papers presented at the 155th Meeting of the Pathological Society of Great Britain and Ireland at Southampton; 8 July, 1987
\end{abstract}

\section{Edited by B. I. DUERDEN}

Introduction. Neisseria meningitidis is a fascinating organism that is capable of causing severe, and sometimes fulminating, infections in man, but only in a small proportion of people who acquire it. In most people the meningococcus colonises the nasopharynx, they carry it for a few weeks or months, and then they eliminate it without having suffered any ill effects; whereas in a small minority, an invasive infection develops that can kill them within hours. In most temperate countries meningococcal infections are sporadic, with occasional clusters of cases. In sub-Saharan West Africa however, true epidemics, with higher attack rates amongst children, occur every few years. During the last 2-3 years (1984-87) the number of cases of meningococcal infection in Britain and Europe has increased, and this has heightened interest in research into the epidemiology, pathogenesis and immunology of meningococcal infection and has stimulated comparisons between situations in Europe and in Africa. The papers presented in this review are based on those given in a Symposium and in the associated free-paper and poster sessions at the meeting of the Pathological Society of Great Britain and Ireland in July, 1987.

Clinical aspects of meningococcal disease

\section{BARBARA BANNISTER \\ Coppetts Wood Hospital, Coppetts Wood, Muswell Hill, London N10 1JN}

Neisseria meningitidis is a bacterial colonist of the upper respiratory tract, and is known to cause localised disease such as conjunctivitis, otitis media, pneumonia, pericarditis and arthritis. Its potential for causing relatively trivial diseases is little researched, but sporadic cases and outbreaks are regularly reported. As a cause of severe bacteraemic disease, particularly acute meningitis, the meningococcus is well recognised. All of its several serogroups can cause sporadic disease, and many have been associated either with smouldering epidemics in temperate countries or with large seasonal epidemics in sub-Saharan Africa.

The most familiar type of meningococcal disease is acute meningitis, characteristically associated with a petechial or purpuric rash. The intensity of the rash is extremely variable, both between

Accepted for publication $20 \mathrm{Jan} .1988$. individual patients and in different epidemics. Different reports of outbreaks and epidemics describe the incidence of rash as being from $40 \%$ to $90 \%$. Some patients have only one or two petechial lesions which may be concealed in, for instance, the mucosal surface of the conjunctival sac. These will not be detected unless actively sought. At the other end of the scale there may be very extensive ecchymotic lesions. These can lead to necrosis and ulceration of skin and subcutaneous tissues, particularly at the knees, elbows, buttocks and face. Fortunately, these lesions are not usually subject to severe secondary infection and they heal well, with skin grafting where necessary, though severe scarring may be unavoidable.

The rash is always accompanied by intravascular coagulation. Early pathological studies revealed blood vessels blocked by fibrin thrombi in which leucocytes and bacteria were trapped (Ferguson and Chapman, 1948). Extensive thrombosis was surrounded by ischaemic breakdown of tissue. Later electronmicroscopic studies (Margaretten $e t$ al., 1967) showed that even apparently normal blood vessels contained fine reticular masses of fibrin, or even free-floating fibrin strands. These changes are accompanied by low plasma fibrinogen levels and a correspondingly low erythrocyte sedimentation rate, together with elevated levels of 
fibrin degradation products and some impairment of platelet aggregation in the presence of adenosine diphosphate.

Because of the high mortality of meningococcal meningitis $(7-8 \%)$ and septicaemia $(12-16 \%)$ several workers have tested the effect of augmenting antimicrobial therapy with heparin treatment. The difficulty of choosing comparable cases for such a trial is considerable, and most series are of patients who presented with shock, who have a relatively uniform mortality rate of about $40 \%$ (Manios et al., 1971; Gérard et al., 1973). Either full doses of heparin or titrated doses, aimed at "normalising" blood fibrinogen levels, were given. In no series was mortality or duration of disease demonstrably altered by heparin, though Gérard et al. thought that the advance of the rash may have been slowed.

Many patients dying with meningococcal disease have bilateral adrenal haemorrhage (WaterhouseFriderichsen syndrome), though it is not known how many survivors have this. When corticosteroid therapy became available, the possible role of adrenal failure in shock and death was extensively investigated. In one particularly large series of cases (Midgeon et al., 1967) the plasma cortisol level was compared with the clinical severity and outcome of disease. Plasma cortisol varied from normal to about $20 \times$ normal, with the most severely ill patients having the highest levels. Only a tiny handful of patients on the point of death had normal or low levels. It is not surprising, therefore, that attempts to treat shock with large doses of hydrocortisone or methyl prednisolone were not significantly successful. Indeed, recipients of corticosteroids seemed more likely than others to develop late neurological sequelae (de Lemos and Haggerty, 1969).

The expansion of laboratory techniques has made available many means of disease diagnosis other than by demonstration of organisms by gramstained film and by culture. Such techniques include counter-immuno-electrophoresis (CIE) (Greenwood et al., 1971), latex agglutination tests (Severin, 1972), estimation of lactate, and estimation of endotoxin levels. All are performed on cerebrospinal fluid (CSF). Only latex agglutination can equal the $70-80 \%$ diagnostic rate of CSF examination by Gram's stain and culture, and even this test is unsatisfactory for detecting the poorly immunogenic group-B meningococci, which are the commonest causes of severe disease in Western countries. Those cases which are difficult to diagnose by culture are also difficult by other diagnostic methods, and this means that it is still important to obtain CSF and to perform more than one type of diagnostic test in difficult cases. A combination of CSF microscopy and culture with CIE increases the diagnostic rate by $4-5 \%$ compared with microscopy alone. Latex agglutination testing will add 8 $10 \%$ to the diagnostic rate by microscopy and culture. Co-agglutination techniques with staphylococcal protein $A$ have also been used, and fall somewhere between the two. Blood culture is usually performed concurrently with CSF examination, and may add $3-5 \%$ to the diagnostic rate.

Antimicrobial chemotherapy for meningococcal disease has changed little since the occurrence of sulphonamide resistance in the mid-1960s. Benzyl penicillin is a safe drug to which meningococci are extremely sensitive. It should be given intravenously, and may be given in large doses in those cases in which tissue damage indicates that high levels of drug should be delivered to tissues as soon as possible. Adults can be given $20-30$ megaunits (14-18 g) daily in divided doses. Although feared by some, penicillin toxicity is rarely a problem. Its most common manifestation is that of a seizure when a large bolus dose is given to initiate therapy. This illustrates how readily the drug reaches the hyperaemic brain, and can even be reassuring in very acute situations. It also adds to the argument that intrathecal therapy has no real advantage over intravenous therapy; indeed, drugs given intrathecally are probably not well distributed in the central nervous system, particularly in older children and adults. Because of this, and the small but important potential for mistakes in dosage, very few clinicians would now advocate intrathecal therapy. Sustained high dosage of penicillin can cause drowsiness, bad dreams or even seizures, but these rapidly disappear if the dose is reduced.

Combinations of drugs cannot be shown to have any advantage over penicillin alone, and in experimental meningitis they have subtle disadvantages in terms of duration of fever and clearance of organisms from the CSF. Therefore, penicillin alone is the treatment of choice in all patients without a definite history of severe penicillin rash or anaphylaxis. In cases of penicillin allergy the second and third generation cephalosporins are excellent alternatives. They too can be given in high intravenous dosage if necessary. The $10 \%$ risk of cross-allergenicity is probably not significantly greater than the risk from other drugs in the penicillin-allergic patient, and is outweighed by their life-saving potential. They can also be used if there is doubt about the aetiology of the infection, as they are effective against Haemophilus influenzae and Streptococcus pneumoniae (though not against Listeria monocytogenes; Hall et al., 1985). They have 
probably replaced the need for chloramphenicol as a drug of second choice, although this remains a useful drug for adults with unusual types of meningitis.

Prompt antimicrobial chemotherapy will terminate all aspects of the disease process within hours in the majority of patients. It has been suggested that exchange transfusion could be a useful adjunct to management of severe cases, but it has the drawback that it cannot remove infected fibrin thrombi from the small blood vessels. In most cases, the issue is settled by other means by the time sufficient blood is cross-matched and available.

Much attention has been given over the years to the part that immunological factors play in the occurrence and prognosis of meningococcal disease. Initial views that immunoglobulin deficiency might be important (Hobbs et al., 1967) have not been substantiated, but there is no doubt that deficiencies of the late components of complement, C5-C9, predispose to frequent or recurrent attacks of meningococcaemia (Ross and Densen, 1984). This is thought to be because, in the absence of antibodies, the main defence against bacteraemic invasion is lysis of organisms by the alternative complement pathway. Recent descriptions of individuals who lack any properdin illustrate this very dramatically (Densen et al., 1987). Properdin stabilises the activated alternative pathway product, $\mathrm{C} 3 \mathrm{bBb}$, which in turn promotes further breakdown of $\mathrm{C} 3$ to $\mathrm{C} 3 \mathrm{~b}$ (fig. 1). Without properdin, $\mathrm{C} 3 \mathrm{bBb}$ breaks down, and the alternative complement pathway activation cannot be sustained. These patients suffer very severe meningococcal disease with a high mortality. If they are immunised, however, they can mount an antibody response and recruit the classical complement

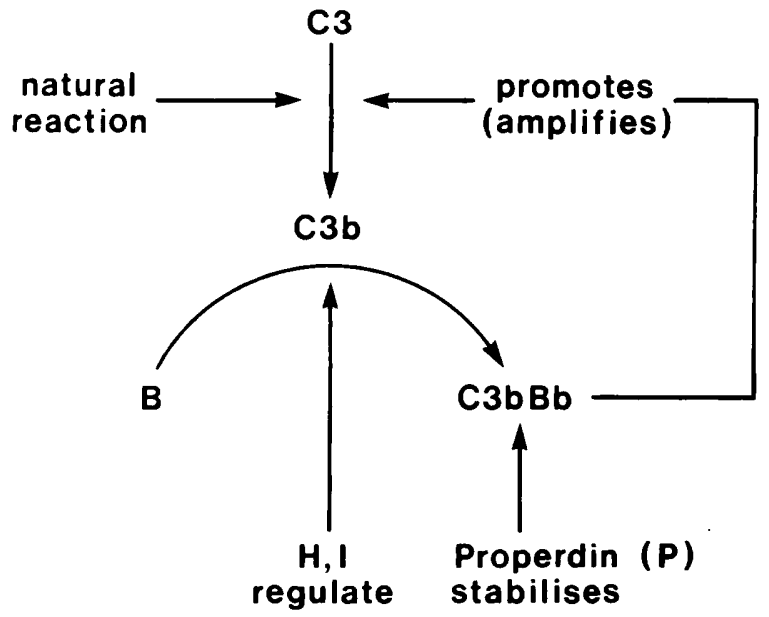

Fig. 1. Properdin and the alternative complement pathway. pathway. Their susceptibility to severe disease is then abolished.

The immunological importance of meningococcal disease does not end with susceptibility. Autoimmune-like disorders can occur after infection, or during prolonged infection. The commonest postinfectious phenomenon is synovitis of large joints, (Pinals and Ropes, 1964), which is often symmetrical and appears 5-10 days after acute disease. Serositis also occurs, though less commonly, causing pericardial and sometimes pleural effusion. Episcleritis has also been described (Whittle et al., 1973). Most of these manifestations are selflimiting, though corticosteroid therapy may be required in cases where pericardial effusion causes tamponade. Meningococcal antigen and deposits of complement can be demonstrated in affected tissues, suggesting involvement of immune complexes in the aetiology of the lesions (Greenwood et al., 1973). In chronic, untreated meningococcal septicaemia, a fluctuating bacteraemia is associated with joint pain and swelling and sometimes with abnormal antibodies in the blood (Orchard et al., 1972). A rash accompanies this disease, but instead of being flat and purpuric, due to intravascular coagulation, it is raised and vasculitic, just like that of Henoch-Schönlein disease. It is important to recognise chronic meningococcal septicaemia as it may suddenly progress to overwhelming disease with shock and extensive tissue necrosis, or with severe endocarditis.

In summary, the meningococcus is an extremely versatile organism. A common colonist of the human upper respiratory tract, it can cause trivial disease, devastating bacteraemic disease with intravascular coagulation and shock, or smouldering systemic disease with a wide range of immunecomplex-type lesions. We are only beginning to understand the pathogenesis and immune responses associated with this range of effects. $N$. meningitidis remains a formidable pathogen, an exacting test of the most advanced technological and clinical resources so far available.

\section{Current problems in meningo- coccal disease}

\section{R. A. WALL}

Microbial Pathogenicity Group. Division of Communicable Disease, C.R.C. Northwick Park, Watford Road, Harrow, Middlesex

Although clinical descriptions of meningococcal disease were first published in 1805 (Vieusseaux, 
1805) and Neisseria meningitidis was first seen in cerebrospinal fluid 100 years ago (Weichselbaum, 1887), there are still major gaps in our knowledge of meningococcal infection. The current resurgence of disease in the UK and Europe, and the continuing problems seen in less developed countries, highlight our ignorance of the cyclical nature of endemic infection, and what generates epidemic disease. Basic problems remain in defining susceptibility to infection, understanding the spectrum of disease and devising control methods.

One of the major barriers to our understanding is that the nasopharynx is the organism's usual habitat and harmless commensalism the usual host-parasite relationship. To cause disease a virulent organism must be transmitted to a mucosal site, overcome local defence mechanisms, invade, evade systemic defences and finally localise-most commonly in the meninges. If we add to this complex scenario different meningococcal strains with different potentials to generate disease, an immense problem requires unravelling.

Much has been learnt of the organism. Less is known of the factors that determine transmission and acquisition, or that determine whether an individual becomes a case or a carrier after exposure.

\section{Transmission}

Since the epidemics of World War II, there has been a relatively low incidence of meningococcal disease although periodic increases in prevalence have occurred about every 10 years. As is characteristic of this endemic pattern, the occurrence of cases is unpredictable, with occasional clusters in various geographical areas, particularly during the periods of increased disease activity (Abbott et al., 1985). Attack rates are highest in those aged under 5 years, and in winter and spring. This illunderstood seasonality is, however, most exaggerated in the "meningitis belt" of Subsahelian Africa (Lapeyssonie, 1963). There, epidemics occur every 7-10 years and last for 2-4 years, but cases occur only in the hot dry months, few if any being identified during the rainy season. Nevertheless during studies in The Gambia (Greenwood et al., 1987) it was evident that even in that environment disease was focal, the epidemic consisting of the sum of clusters of cases.

The risk of meningococcal disease is a function of the rate of person-to-person transmission (Griffiss, 1982). Point prevalence carrier surveys are of little help in understanding this risk (Wenzel et al., 1973), although they have helped to identify the higher carriage rates in the close contacts of index cases (Kaiser et al., 1974; De Wals et al., 1981) and have stressed the importance of the closeness of contact as a risk factor in secondary cases (Meningococcal Disease Surveillance Group, 1976).

Longitudinal studies are required to address the dynamics of transmission but are difficult to carry out (Griffiss, 1982). In a study of American families, in which diseáse was not occurring, 41 households were studied for up to 32 months (Greenfield et al., 1971). Nasopharyngeal cultures were obtained every 2 months from 238 individuals. In this epidemiological setting, adult males were most likely to introduce meningococci into a family. Intra-family spread was slow, with a new acquisition rate of $0.5 \%$ per month. No factor associated with transmission could be identified. Longitudinal studies in a Northern Nigerian village in an epidemic focus, but in which disease was not identified, revealed a new acquisition rate of $1.6 \%$ per month with children identified most frequently as the first carrier in a household (Blakebrough et al., 1982). During the Gambian studies an acquisition rate of $1.5 \%$ per month was seen in a village in which disease did not occur, but this rate increased to $4.6 \%$ per month in an affected village.

These results imply that enhanced transmission is a feature of meningococcal spread in West Africa and may contribute to the development of outbreaks. They also suggest that even within an epidemic focus some further factor may increase transmission and be involved in the generation of disease. Whether this factor is co-existant respiratory viral infection, aiding meningococcal dispersal, is unproven, but strongly suggested by studies of outbreaks in the American Armed Forces (Edwards et al., 1977), or sporadic cases in civilians (Olcen et al., 1981).

\section{Acquisition}

In The Gambia, as elsewhere in the meningitis belt, the maximal attack rate occurred within the age group 5-15 years; this group accounted for $50 \%$ of all cases (Greenwood et al., 1987). There was relative sparing of those aged under 4 years who accounted for only $15 \%$ of cases, suggesting that this age group was less frequently exposed, acquired the organism less often, or was less susceptible. Exposure to the epidemic strain was assessed by nasopharyngeal culture, and the prevalence of anticapsular antibody. Exposure, also, was maximal in the age group 5-15 years, which accounted for $40 \%$ of the total identified as exposed, thus reinforcing the concept that within this environment transmis- 
sion occurs most frequently amongst these children (Blakebrough and Gilles, 1980). Those under 4 years old accounted for only $20 \%$ of the cases, and $15 \%$ of the carriers. Thus children in this age group were either less exposed, or acquired the organism less often, but if exposed had high attack rates. Since exposure is unlikely to be different, these findings imply that within a similar community, some factor in addition to the presence of the organism, affects acquisition.

Studies during an outbreak of meningococcal disease in "skid row" populations in the USA (Filice et al., 1985) suggested that certain microorganisms of the normal respiratory flora may inhibit meningococcal acquisition. Other mechanisms, including genetic factors (Blackwell et al., 1986), also warrant further study.

\section{Susceptibility to disease}

Having been exposed to and acquired a pathogenic meningococcal strain, what determines whether disease or carriage will result? That humoral immune mechanisms are involved was suggested by the inverse relationship between the age of maximal disease incidence, and the agerelated prevalence of bactericidal antibody in invitro tests (Fothergill and Wright, 1933; Goldschneider et al., 1969). Antibodies to various meningococcal fractions including capsule, outermembrane proteins and lipo-oligosaccharides (Zollinger et al., 1974) can be demonstrated by a range of in-vitro assays. The important issue, however, is which antigens and which in-vitro tests can be used to determine protective antibody. The keynote studies in the American Armed Forces (Goldschneider et al., 1969) correlated susceptibility to disease with the absence of bactericidal antibody, and showed that immunisation with capsular polysaccharide could induce such antibodies (Gotschlich et al., 1969).

Although others have shown that other components, particularly outer-membrane proteins (Frasch, 1977; Zollinger et al.,1978) can induce an immune response, in practice only anti-capsular antibody (Makela et al., 1977) or bactericidal antibody have been associated with protection. Subsequent studies suggested that the absence of bactericidal antibody, and hence susceptibility, could be induced by blocking $\operatorname{IgA}$ antibodies (Griffiss and Bertram, 1977). The role of complement in host defence is emphasised by the predisposition to meningococcal disease of individuals who lack terminal components of the complement cascade (Nicholson and Lepow, 1979).
These correlations with susceptibility were investigated during epidemic disease in The Gambia (Greenwood et al., 1987). Sera which had been taken 3 or 9 months before the epidemic, from individuals who subsequently became cases and their age-matched controls, were analysed by indirect haemagglutination for anti-capsular antibody, by indirect immunofluorescence for $\mathrm{IgG}$, IgM and IgA to whole cells, and by bactericidal assays. No significant differences were detected between cases and controls. In particular, four culture-proven cases had bactericidal antibody in their pre-disease sera. Whether these antibodies had declined by the time of the epidemic, or whether blocking antibodies had developed was impossible to assess and remains conjectural. Perhaps more important may be variation in the organism itself. The epidemic strain was clonal in origin (Crowe et al., 1986) but the composition of the outer membrane of gram-negative bacteria can vary depending on growth conditions (Dalhoff, 1985). Variation in the major outer-membrane proteins can be seen during the course of infection (Tinsley and Heckels, 1986) and the expression of class- 5 and class- 1 proteins can vary depending on the site of isolation in a diseased individual (Poolman et al., 1980). Such phenotypic variation could significantly influence in-vitro bactericidal assays, in the absence of anti-capsular antibodies. Alternatively, protection may be only associated with bactericidal antibody, not causally linked, and other defence mechanisms, particularly phagocytosis, may have an important role (Ross et al., 1987).

Subsequent studies (Wall, unpublished data) suggest that some individuals who subsequently became carriers, not cases, lacked antibody in their pre-colonisation sera. Thus not only does bactericidal antibody appear to fail to protect in this environment, but its absence does not equate with susceptibility. Some further factor, as yet unknown, appears to influence the generation of disease.

Failure to identify these unknown factors will continue to make meningococcal disease the capricious infection it has always been.

\section{Epidemiology of meningococcal infection in England and Wales}

\section{M. JONES \\ Public Health Laboratory, Manchester M20 8LR}

Meningococcal infection first became notifiable in 1912. Although notifications may account for 


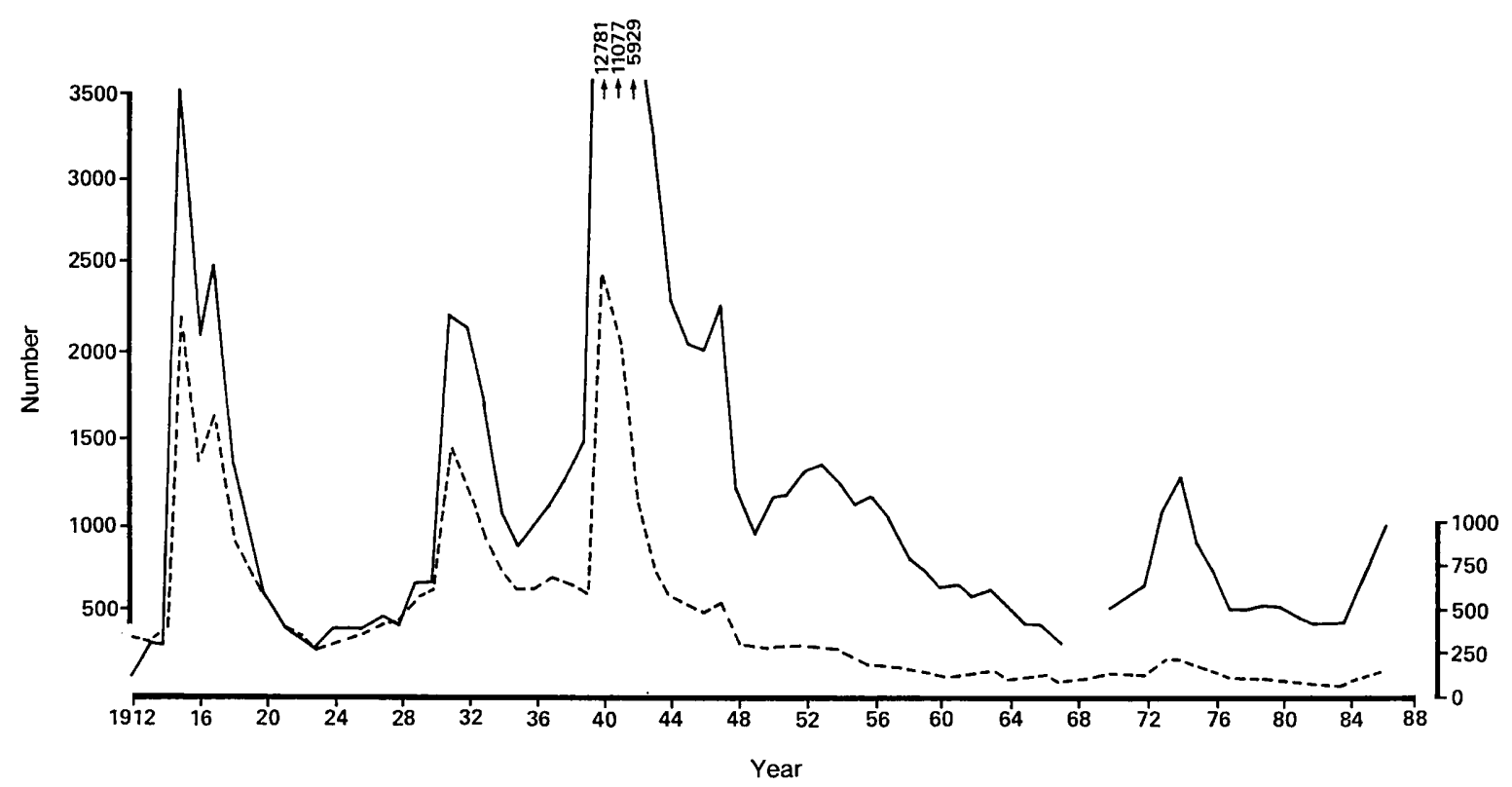

Fig. 2. Meningococcal infections in England and Wales 1912-1987; notifications_-_, deaths- - -

only about half the actual amount of disease they do provide us with a continuous record of trends since 1912. There have been three great peaks of infection; those associated with the Great War and the Second World War both occurred at times when there was great social upheaval, but there was also a high peak in the early 1930 s (fig. 2). Each of these large increases in infection was associated with group-A meningococci. Group-A infections have now largely disappeared from England and Wales and, on average, there are no more than 20 or 30 cases a year. In a recent carrier survey only three people out of nearly 7000 were found to be carrying group-A strains, so clearly this organism is not only causing little disease but is very uncommon in the nasopharynx of individuals in this country. The basic level of endemic disease has been between 400 and 500 notifications each year since 1960 , but this was interrupted during the 1970 s when there was a peak; notifications rose to 1200 in 1974 and this increase in infection was accounted for largely by the appearance of a "new" strain, group B serotype 2. This organism caused widespread sporadic disease and several outbreaks around the country but had disappeared again by the late 1970s. Since 1985 the total amount of meningococcal disease has been increasing again and there were 850 notifications in 1986 and in 1987 this figure was exceeded.

When the serogroups of meningococci causing disease are examined, generally $60-70 \%$ of infec- tions are caused by group-B strains, although over the last decade the proportion of infections caused by group-C strains has varied and is presently increasing; in 1986 some $40 \%$ of infections were caused by group-C strains while group-A strains accounted for only $2 \%$ (fig. 3 ).

This increase in group-C infection is important in so far as small clusters of infection caused by group-C strains are more likely to be encountered in schools, military camps etc, and, as there is an effective group-C vaccine, occasionally there will

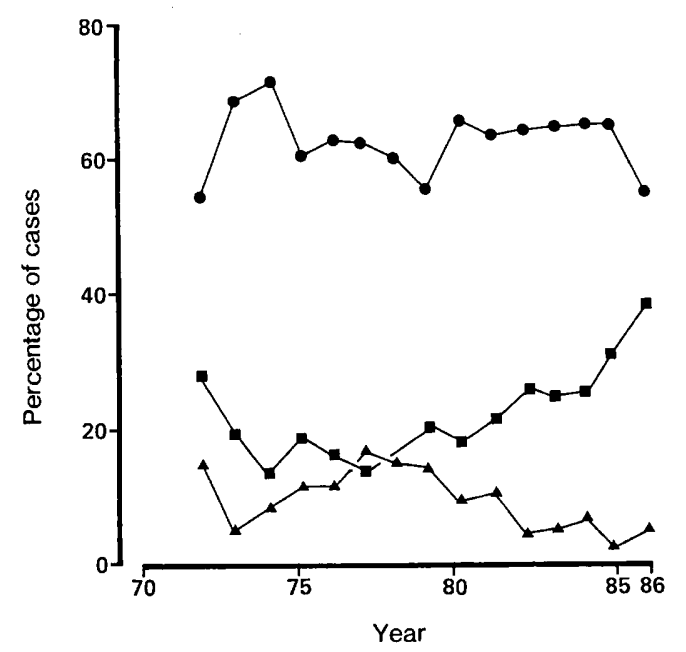

Fig. 3. Proportion of disease caused by meningococci of serogroups $A(\boldsymbol{\Delta}), \mathrm{B}(\bullet)$ and $\mathrm{C}(\boldsymbol{\square})$. 


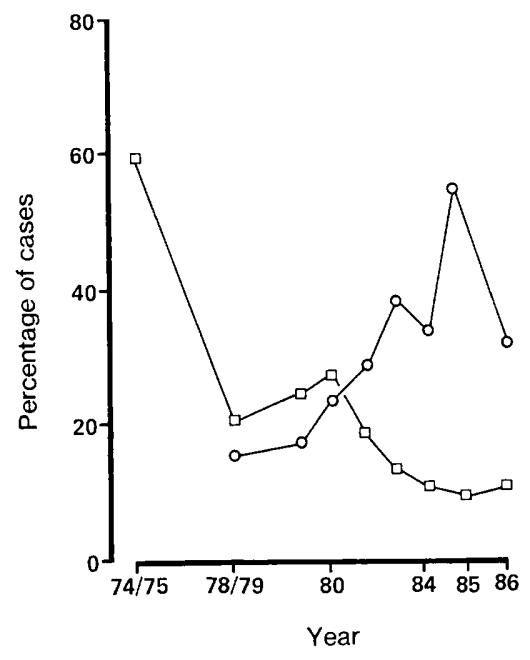

Fig. 4. Proportions of group-B infections caused by serotypes 2 () and $15(0), 1974-1986$.

be indications for using the vaccine. In 1986-87 vaccine has been given to recruits in two military camps following clusters of group-C cases and also to 1000 schoolchildren in a school where there were four cases of group-C infection in the space of one week. If group-B disease is considered, in the middle $1970 \mathrm{~s} 60 \%$ of infections were caused by serotype 2 , but thereafter serotype- 2 strains became progressively less common and currently account for only $c .10 \%$ of group-B infections. Serotype 15 , on the other hand, has slowly become more important and has replaced type 2 as the predominant serotype amongst group-B strains (fig. 4). Serotype-15 infections reached a zenith in 1985 when nearly $50 \%$ of infections were caused by this serotype; since then the proportion has started to fall steadily and in the first part of 1987 these strains accounted for only $28 \%$ of the group-B infections. Normally, meningococcal disease occurs predominantly in children under 5 years old. When the age of those patients who are infected by the different serotypes of group-B meningococci are analysed, it is found that, for most serotypes, three quarters of infections occur in those under 5 years old, but for serotype- 15 strains, only $35 \%$ of cases are in this age group. If the serotypes are further subdivided, type-15 sulphonamide-resistant strains, as opposed to the sensitive strains, are found to have a particular predilection for causing infections in the 10-25 age group. With the advent of monoclonal antibodies to detect subtype antigens, group-B type15 subtype-16 (B15P1.16) strains have been found to be exclusively sulphonamide resistant and to have this property of being liable to cause infection in teenagers and young adults. These strains have also been the cause of local outbreaks such as those recorded in Stroud and in Plymouth. The property of being able to infect the older age groups also appears to reside in other serotypes that are sulphonamide resistant, so it would appear that sulphonamide resistance is a marker for some pathogenicity factor, expressed by the organism and as yet unidentified, which renders teenagers and young adults just as susceptible to these infections as are children under 5 years old.

During the last 2 years there has been an overall increase in the total number of infections, and group- $\mathrm{C}$ strains have caused an increasing proportion of these (fig. 5). At the same time group-B type15 strains may be becoming less important and, amongst group-B strains, those that are non-typable have increased in importance. In the first part of 1987 , nearly $50 \%$ of the group-B strains were non-

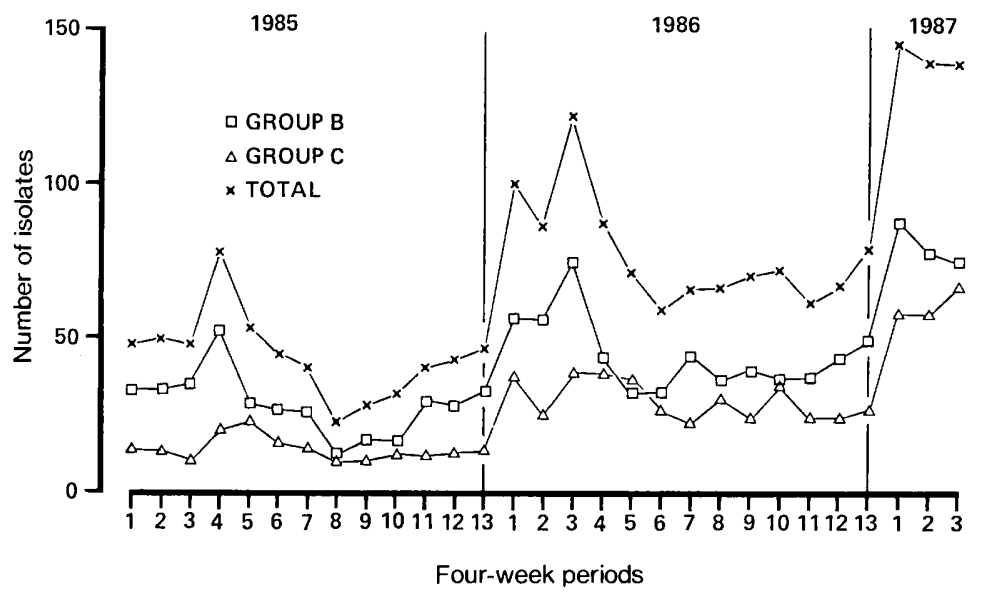

Fig. 5. Number of meningococci (4-weekly totals) received at Manchester PHL from clinical cases 1985, 1986, 1987 (1st quarter); total $(x)$ group B $(\square)$, group $C(\triangle)$. 
typable. From preliminary work in collaboration with Drs Abdillahi and Poolman, who have prepared a wide range of typing and subtyping monoclonal antibodies, it is likely that amongst these "non-typable" strains, serotype 4 may be quite common. If this is confirmed the place of the type- 15 strains may be taken by serotype 4 .

In summary, the overall amount of meningococcal disease is increasing in England and Wales but strains of serotype B15P1.16 are a diminishing proportion of these infections. As these strains were associated particularly with disease in teenagers and young adults it is possible that this pattern of disease will become less common. Group-C strains are causing an increasing amount of infection and there will be opportunities for using the vaccine to control any outbreaks that occur. With regard to serotypes of group-B meningococci, it seems likely that as serotype B 15 decreases its place may be taken by a new serotype(s), possible serotype 4 . This is important for those concerned with the construction of outer-membrane-protein meningococcal vaccines because, as far as England and Wales are concerned, a vaccine containing serotype 15 may now no longer be necessary and attention must be turned to other outer-membrane-protein constituents.

It would not have been possible to compile this important surveillance data on meningococcal disease without the cooperation of medical microbiologists throughout England and Wales.

\section{Meningococcal infections in Scotland}

\section{R. J.FALLON}

Department of Laboratory Medicine, Ruchill Hospital, Glasgow G20 9NB

Meningococcal infections in Scotland have been under detailed bacteriological surveillance since 1970 and a detailed analysis of findings for the years 1972-82 has been published (Fallon et al., 1984). There are three recording systems: (1) clinical disease notified to the Registrar General for Scotland; (2) laboratory isolations notified to the Communicable Diseases (Scotland) Unit (CDSU); (3) cultures received by the Meningococcus Reference Laboratory (Scotland). Until 1975, the Registrar General's figures were only for "cerebrospinal fever" and may have included other causes of meningitis and omitted meningococcal septicae- mia. From 1975 onwards, these figures have included both meningococcal meningitis and septicaemia. Notifications of clinical disease are known to be prone to error and, like those of laboratory isolations, will be incomplete in so far as not all cases are notified. This latter point has been emphasised by the fact that although cultures received by the Meningococcus Reference Laboratory represent a high proportion (usually well over $80 \%$ ) of meningococci notified as isolated to the CDSU, cultures are also received from cases which have not been notified. The notifications of deaths to the Registrar General are more likely to be comprehensive than those based on laboratory isolations, but a number of fatal cases do not have any bacteriological proof because cultures are not taken before death nor at autopsy.

Cultures sent to the Reference Laboratory are confirmed as meningococci and are serogrouped, typed and subtyped, and their sensitivity to antibiotics and sulphadiazine is established. Information on age, sex, whether the patient had a pure septicaemia or meningitis with or without septicaemia, and the outcome of disease, is sought for all patients with systemic disease from whom cultures have been received. Serogrouping is performed either by slide or co-agglutination methods with sera produced in the laboratory from hyperimmunised rabbits. However, recent batches of commercially-available antisera have been found to be satisfactory. Serotyping of meningococci was performed by gel diffusion with rabbit antisera to the protein types described by Frasch et al. (1985b) but has been superseded by co-agglutination. More recently, monoclonal antibodies to types $2 \mathrm{a}, 2 \mathrm{~b}, 2 \mathrm{c}$ and, very recently, type 4, provided by Drs Zollinger of Washington and Poolman of Bilthoven, have been used and represent a great improvement over rabbit antisera. Subtyping based on monoclonal antibodies to the class-1 proteins of $N$. meningitidis, again supplied by Drs Zollinger and Poolman, has also been carried out in recent years. At present, many strains of group-B and group- $\mathrm{C} N$. meningitidis cannot be typed with currently available reagents and investigations into further typing are in progress.

The notifications of clinical meningococcal disease generally parallel the overall figures for strains isolated and forwarded for examination to the Reference Laboratory (fig. 6). Traditionally, the overall notification rate for Scotland has been higher than in England and Wales, although this may not apply in detail because of regional variations in prevalence. The increased prevalence of infection in 1974, which although affecting the 


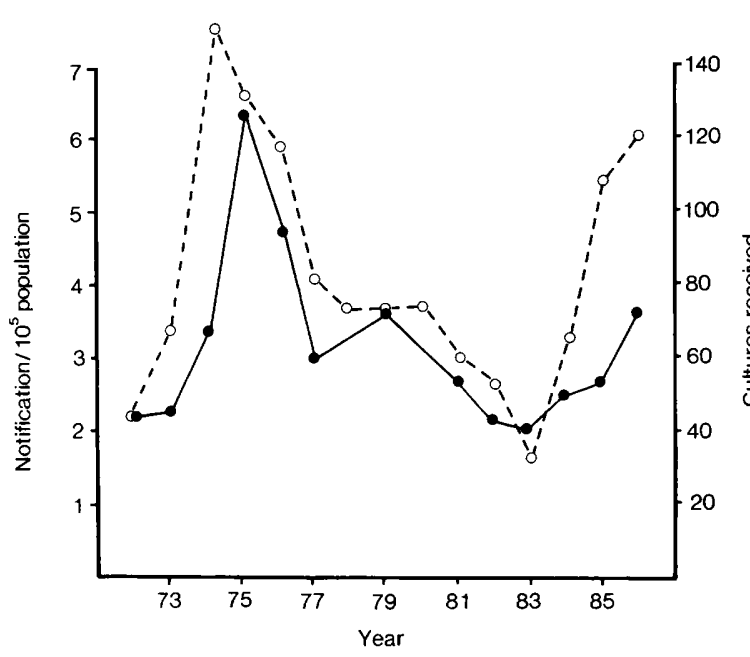

Fig. 6. Meningococcal infections in Scotland 1973-86; notification of disease, $0---\circ$ cultures received.

whole of the UK did not attract publicity, is well shown in the number of cultures received, but as meningococcal septicaemia was not notifiable until 1975 the notification rate did not rise so dramatically. It is interesting that the much lower figures for 1985 and 1986 did, however, attract much publicity, probably because several fatal cases occurred in patients of school-age rather than in babies. As in the rest of the UK, the highest number of notifications is usually in the first quarter of the year and is a useful indicator of how the pattern is likely to develop in the rest of the year. Hence, the increasing level of infection seen in 1985 and 1986 was heralded by higher numbers in the first quarters of those years than in the same periods in the previous years. The number of cases in the first quarter of 1987 was slightly lower than that in the same period of 1986 but there were slightly more cases in the second quarter of the year than in the corresponding period of 1986, so that in 1987 there were slightly more laboratory notifications in the first half of the year than in the same period for any of the preceding years since 1975. The increase in prevalence of disease in Scotland in recent years was first noticed in Lanarkshire in 1984. However, the increase has been seen in both east and west Scotland and, unlike in England and Wales, there have been no local outbreaks of disease.

The numbers of strains of the main serogroups of $N$. meningitidis isolated in Scotland are shown in fig. 7. The increased prevalence of infection in 1974-76 was mainly due to group B which predominated in succeeding years. However, although group-B infection was prevalent in the latter part

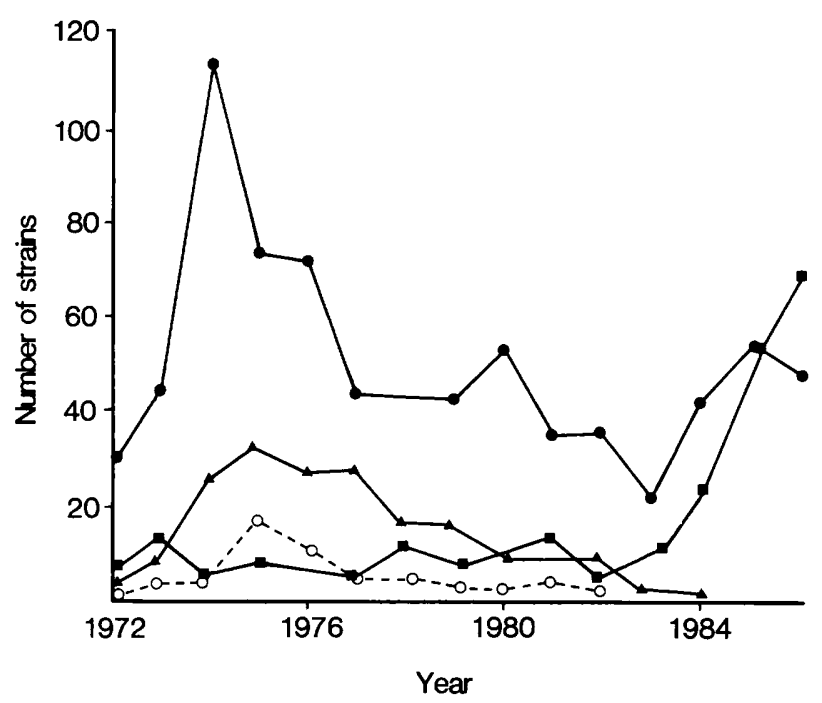

Fig. 7. Principal serogroups of $N$. meningitidis isolated in Scotland

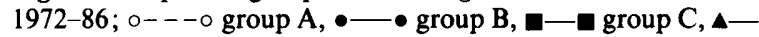
$\Delta$ group W135.

of 1984, group-C strains have increased in prevalence since that time and now predominate, a situation which has not been seen in Scotland since laboratory surveillance of infections commenced. Meningococci of groups A and W135 were prevalent in the 1970s but now form only a small proportion of strains isolated from cases. Although meningococcal infections principally affect those under 5 years old there is a difference in the age distribution of cases caused by different serogroups as noted by Fallon et al. (1984). Hence, meningococci of groups $\mathrm{A}$ and $\mathrm{C}$ tend to affect young children less and adults more than group-B strains.

The principal serotypes of $N$. meningitidis isolated in Scotland are shown in table I. These results are derived from testing with both polyclonal and monoclonal antibodies because monoclonal antibodies have only been available in recent years. Group-B strains of type 2, later subdivided into types 2a, 2b and 2c (Poolman et al., 1980) were found by Frasch (1977) to be those most commonly associated with disease. However, in 1976, strains of a new serotype, 15 , were identified as the cause of a severe epidemic of infection in northern Norway and such strains spread to most of northwest Europe (Poolman et al., 1986). However, the picture has been less clear-cut in Scotland. Type-2 strains predominated in 1977-78, in 1981, and then in 1984-86, the numbers of type-15 strains falling in 1986 and remaining low in 1987. However, many strains remain untypable and are currently under investigation. As first noted by Jones et al. (1986) 
Table I. Principal serotypes of meningococci isolated in Scotland

\begin{tabular}{c|rrrc}
\hline & \multicolumn{4}{|c}{ Percentage of strains that were serotype } \\
\cline { 2 - 5 } Year & 1 & 2 & 15 & Untypable \\
\hline 1977 & 0 & 54 & 4 & 37 \\
1978 & 0 & 53 & 6 & 35 \\
1979 & 0 & 12 & 23 & 65 \\
1980 & 0 & 6 & 28 & 50 \\
1981 & 6 & 32 & 9 & 38 \\
1982 & 0 & 14 & 25 & 53 \\
1983 & 10 & 10 & 19 & 61 \\
1984 & 12 & 29 & 7 & 48 \\
1985 & 7 & 28 & 24 & 41 \\
1986 & 0 & 29 & 8 & 56 \\
& & & & \\
\hline
\end{tabular}

in England and Wales, strains of subtype B15P1.16 isolated in Scotland have been resistant to sulphonamides and gave rise to disease in older patients (principally young adults) than is generally seen with group-B strains. Group-C strains isolated in 1985 and 1986 have mainly been of type $2 \mathrm{~b}$ (C2b-) or C2bP1.2 although there were some strains of $\mathrm{C} 2 \mathrm{a}-$ isolated in 1986. There is no particular geographical distribution of the types of group-C strains isolated from patients. The increased prevalence of group-C meningococci and their observed age association may result in infection in older patients being more prevalent than in previous years. However, outbreaks of group-C infection are amenable to prevention and control by vaccination, as has already been employed in Denmark and in England.

Sulphonamide resistance has been noted in meningococci isolated in Scotland since 1970 and has always been seen in a high proportion of groupA strains and now in B15P1.16. All the strains of group $\mathrm{C} 2 \mathrm{a}$ - isolated in 1987 have been resistant to sulphonamides and have tended to be associated with older patients. The considerable proportion of strains of all serogroups resistant to sulphonamides (14-28\%) has precluded the blind use of sulphonamides for prophylaxis, but rifampicin, to which almost all meningococci isolated in Scotland have been sensitive, is effective for this purpose.

Figures for the outcome of clinical disease for the years 1972-1982 were presented by Fallon et al. (1984) in detail. They showed that, in cases from whom a positive culture was obtained, mortality in meningitis was $7.5 \%$, ranging from $4.7 \%$ with group-B infection to $12.6 \%$ with group-A infection. In septicaemia it was $20.6 \%$ overall. The average for all cases was $9 \cdot 4 \%$. Figures for recent years based on laboratory isolations have been unreliable because cultures have not been obtained from several known fatal cases so that the overall figure of $3 \%$ is suspect. Figures from the Registrar General's returns for Scotland in the two periods show a mortality of $8 \%$ for the period $1972-82$ (septicaemia not being notifiable for the earlier part of that period) but only $4.9 \%$ for the period $1983-$ 86. This suggests that there may have been a slight reduction of overall mortality in the recent past.

\section{Meningococcal vaccines}

\section{J.T.POOLMAN}

Department of Bacterial Vaccine Development, RIVM PO Box 1, 3720 BA Bilthoven. The Netherlands

There is a close relationship between the presence of bactericidal antibodies and susceptibility to meningococcal infections. This relationship was unambiguously proven by Heist (1922), who lacked bactericidal activity against the strains he was working with in the laboratory and died of meningococcal meningitis. Later, Goldschneider $e t$ al. (1969) demonstrated that individuals lacking bactericidal antibodies against a circulating virulent strain had a high risk of acquiring meningococcal meningitis. The protective bactericidal antibodies detected in the base-line sera were directed against type-specific antigens and at least two group-C strains were circulating at that time, only one of which was causing disease. The typespecific antigens of meningococci were later identified as outer-membrane proteins (OMPs) or lipopolysaccharides (LPS), or both, as summarised by Frasch et al. (1985a). The important role of complement is illustrated by the susceptibility of complement-deficient individuals to meningococcal diseases. In particular, C6-, C7-and C8-deficient people appear to be susceptible rather specifically to neisserial diseases. This indicates that meningococci are relatively resistant to phagocytosis, in comparison, for instance, with another encapsulated gram-negative species that causes meningitis, Haemophilus influenzae type $b$.

In the late 1960s and early 1970s, it was found that purified group-A and group-C meningococcal capsular polysaccharides eould induce bactericidal antibodies when used for immunisation (Wyle et al., 1972). Protection against meningococcal diseases was thereafter proven in several field trials with these polysaccharide vaccines. On the basis of 
these results, tetravalent $\mathrm{A}, \mathrm{C}, \mathrm{W}, \mathrm{Y}$ polysaccharide vaccines have been developed (Peltola et al., 1977). However, a number of drawbacks are associated with the meningococcal polysaccharide vaccines:

(i) Polysaccharides are type-2 T-cell independent antigens (Ti-2); they do not give an appropriate immune response in the very young and do not induce immunological memory, i.e., long-lasting immunity. The relatively short duration of protection (3-4 years) was demonstrated in the field, as was the inability of the group-C polysaccharide to induce an immune response in children below the age of 2 years. These problems can be circumvented by covalently linking the polysaccharide antigens to proteins (Beuvery et al., 1983). This approach has now reached clinical evaluation in siblings in the case of $H$. influenzae type b polysaccharideprotein conjugates, with induction of antibodies in this age-group normally not responsive to the plain polysaccharide (Eskola et al., 1985).

(ii) A major problem in the development of vaccines against meningococcal diseases is the group-B capsular polysaccharide, a homopolymer of $\alpha(2 \rightarrow 8)$-sialic acid, that is poorly immunogenic (Wyle et al., 1972). The linear sugar epitopes of this polysaccharide do not seem to be immunogenic at all and the low-affinity antibodies, when induced, appear to be directed against conformational epitopes (Jennings et al., 1985). An explanation for this can be found in the presence of $\alpha(2 \rightarrow 8)$-sialic acid-containing biomolecules in the human host (Finne et al., 1983). Interestingly, by replacing the $\mathrm{N}$-acetyl by $\mathrm{N}$-propionyl in the group-B polysaccharide, it appears to be possible to induce groupspecific bactericidal antibodies that cannot be absorbed with the unmodified polysaccharide (Jennings et al., 1987). A possible explanation is that this epitope mimics the chemical bond between the polysaccharide and the lipids sticking it into the outer membrane (Gotschlich et al., 1981). It is important to define chemically this newly discovered epitope and it may eventually become possible to induce the desired antibodies without inducing the $\alpha(2 \rightarrow 8)$-sialic acid-specific antibodies that can be potentially hazardous because of auto-immune effects.

(iii) Antibodies against the meningococcal capsular polysaccharides may not be those with the strongest bactericidal potency, since for that a close proximity to the outer membrane is needed. Anticapsular immunity may depend more upon phagocytosis. Furthermore, the data on C6-, C7-, C8deficient patients can best be explained by assuming that phagocytosis alone is not always enough to resist meningococcal disease.
Taking together all of these points, it is clear that we need to identify protective antigens other than the capsular polysaccharides to construct efficacious meningococcal vaccines. The type-specific outermembrane antigens, outer-membrane proteins and lipopoly (or oligo) saccharides (LOS), demand our attention (Frasch et al., 1985a). Two phenomena have to be kept in mind when trying to identify protective epitopes within the meningococcal outer membrane:

(i) genotypic variability - meningococci can rapidly change their antigenic make-up by varying qualitatively the class-5 OMPs, pili and LOS (Poolman et al., 1980, 1985; Tinsley and Heckels, 1986); patients with meningococcal meningitis do respond preferentially to the class-5 OMP but mostly against the strain-specific epitopes (Poolman and Zanen, 1980).

(ii) phenotypic variability-meningococci adapt their outer-membrane composition to the growth conditions, such as iron limitation, growth rate or glucose limitation (Putten et al., 1987).

Of particular importance is the observation that meningococci can vary the rate of expression of the class-1 OMP in vivo (Poolman et al., 1980). It is hard to determine the appearance of meningococci in vivo, but antibody. responses and direct investigations on meningococci in cerebrospinal fluid, with immuno-electronmicroscopy and monoclonal antibodies, can be of some help.

Meningococci can thus be considered to be true chameleons, and it will be difficult to find appropriate protective epitopes. Although OMPs induced by various growth conditions are clearly important research subjects, the second part of this section will be dedicated to the OMPs and LOS of meningococci that can be recognised irrespective of the growth condition-polysaccharides (PS), LOS, and class 1, 2/3, 4 and 5 OMPs. Which of the outer-membrane components are suitable vaccine candidates? Clearly the only way to determine this will be the evaluation of field trials with outermembrane-component vaccines. The selection of the composition of the first such vaccines to be tested depends upon:

(i) the outer-membrane characteristics of the major disease-causing strains in the country where a vaccine trial will be carried out (this will be discussed at the end of the section, and

(ii) the outer-membrane components suspected to be protective antigens.

This type of vaccine can be described as a first generation OMP vaccine. Lipopoly (or oligo) saccharides must not be included, i.e., they must be reduced to acceptable minimal levels, because of 
their endotoxic activity. It is disputable whether class-5 OMPs need to be included, as in some vaccines (Frasch et al., 1985a). Arguments against this are:

(a) The high variability of class-5 OMPs. The strain-specific epitopes are immunodominant and the total repertoire of different class- 5 epitopes amongst meningococci is unknown. Conserved epitopes do appear to exist (T. Meyer, personal communication), but it remains to be seen whether they can be of practical use.

(b) Class-5 OMPs probably contain a receptorbinding domain for host receptors, for example on lymphocytes, like the gonococcal pII (Swanson and King, 1978), which may interfere with the antibody response to other components.

Because of these problems, some outer-membrane-protein vaccines have been constructed which exclude the class-5 OMP (Zollinger et al., 1979; Poolman et al., 1987). These vaccines consist of two OMPs, the class- 1 and $-2 / 3$ OMPs, accepting the presence of some class-4 OMP and LOS, which cannot be eliminated. The LOS may work as an adjuvant and the amount of LOS might, therefore, have a profound effect on the immune response. In the final vaccine preparations, either aluminium phosphate or aluminium hydroxide is included as adjuvant. Studies with murine monoclonal antibodies demonstrate that antibodies against class-1 OMP and LOS are bactericidal. Antibodies against the class-2/3 OMP are only weakly bactericidal, particularly when the test bacteria are grown to stationary phase or in conditions of glucose limitation (Poolman et al., 1987). These results were confirmed by testing the protective capacity of these monoclonal antibodies in an infant rat meningitis model (Saukkonen et al., 1987). The current vaccine trials (Frøholm et al., 1986) with these first generation outer-membrane-protein vaccines will eventually allow the identification of the epitopes capable of inducing bactericidal, protective antibodies in man. Unfortunately, meningococci are rather heterogeneous with respect to the class -1 and $-2 / 3$ OMPs, this being the basis of a serosubtyping system (Frasch et al., 1985a). Because of this, the first generation OMP vaccine can only be used in situations in which most cases of meningococcal disease are caused by a single strain or a combination of strains sharing the same serosubtyping characteristics.

The serosubtyping of strains thus becomes an important part of vaccine-related studies. A hybridoma bank is being built up, to enable serosubtyping of most strains, particularly those belonging to group B. It is known that serosubtypes change with time and by geographical area (Poolman et al., 1986). Interestingly, one particular serosubtype combination ( $2 \mathrm{~b} 1.2$ ) was demonstrated to have remained a problem for more than 20 years in the Netherlands, before replacement with other serosubtype combinations, indicating the importance of host immunity in the epidemiology of the disease. Presently, approximately $80 \%$ of group-B strains from various countries around the world can be class- $2 / 3$ OMP-serotyped and also $80 \%$ can be class1 OMP-subtyped (Abdillahi, this review). Class-1 OMPs of group-B meningococci appear to share epitopes with class-1 OMPs of group-A meningococci (Crowe, this review). The current rise in incidence in England, Denmark and the Netherlands can be shown to be caused by several different strains, such as B15P1.16, B4P1.15, C2aP1.2. (Jones, this review; Lind, personal communication; unpublished results from the Netherlands). These data taken together indicate that there is a need for a second generation OMP vaccine that would protect against disease caused by strains having different serosubtype characteristics. If the data about bactericidal activity of monoclonal antibodies and animal protection studies pointing to the class-1 OMP as a protective antigen are extended by data from human vaccinees, a multivalent class-1 OMP vaccine will be worth pursuing. However, the ability of meningococci to alter the rate of expression of this protein (Poolman et al., 1980) is a point of serious consideration. Alternative approaches, such as a definition of a protective epitope associated with the group-B polysaccharide, chemical characterisation of LOS protective epitopes, and perhaps others, still need attention.

\section{Recent results on epidemic meningococcal meningitis}

M. ACHTMAN, B. A. CROWE, A. OLYHOEK, W. STRITTMATTER and G. MORELLI

\section{Max-Planck-Institut für molekulare Genetik, West Berlin}

Epidemics of meningococcal meningitis caused by serogroup-A bacteria occur in cyclic waves approximately every decade and have been documented since the beginning of this century (Lapeyssonnie, 1963; Peltola, 1983; Olyhoek et al., 1987). Since the Second World War, these waves have been most dramatic in West Africa and China and of lesser importance in Europe and North America, where most disease is of endemic nature and most 
cases of meningococcal meningitis and septicaemia are caused by serogroup-B organisms. The development of polysaccharide A vaccine in the early $1970 \mathrm{~s}$ (Gotschlich et al., 1969, 1978) has supplied a relatively expensive tool to interrupt epidemics by ad hoc immunisation of whole populations, but preventive immunisation (preferably of young children) is still not possible.

Currently available serological typing of serogroup-A bacteria has been based on outer-membrane protein and LPS antigens (Frasch et al., 1976; Zollinger and Mandrell, 1980) but has not yielded any striking epidemiological conclusions (Olyhoek et al., 1987). Very recently, the techniques of clonal analysis (Selander et al., 1986, 1987; Achtman and Pluschke, 1986) have been applied to Neisseria meningitidis (Caugant et al., 1986a and $b, 1987$; Olyhoek et al., 1987) and the results with serogroup-A organisms have revealed world-wide patterns to the epidemic waves seen since 1962 (Olyhoek et al., 1987).

A collection of 423 serogroup-A meningococci was assembled by requesting strains from reference laboratories. Most of the bacteria were isolated from patients with meningitis but a few were from healthy carriers. Many strains came from epidemic years while others came from inter-epidemic periods; 23 epidemics and 38 different countries in 6 continents were represented. Variable migration of the class- 1 protein and the expression of the class- 6 protein were scored after SDS-PAGE of outermembrane preparations; the variable migration of seven isoenzymes was scored after starch gel electrophoresis of cytoplasmic preparations. After combinations containing null alleles for one of these nine properties were excluded, it was possible to distinguish 34 distinct electrophoretic types. These were analysed by average linkage clustering of a weighted distance matrix to yield the dendrogram shown in fig. 8. Based on numerical analysis of the data and subjective interpretation of the epidemiological sources, the 34 electrophoretic types were assigned to four serogroup-A subgroups (AI-AIV) and 21 clones (labelled sequentially within each subgroup; I-1, I-2, etc.) as shown in fig. 8. Detailed results have been presented elsewhere (Olyhoek $e t$ al., 1987) and only the most important conclusions are presented here.

Clone I-1 was responsible for a pandemic which began in 1967 in North Africa and various Mediterranean countries and spread throughout West Africa within the next 2 years. This clone caused other African epidemics in the late 1970s (Nigeria, Rwanda) and a well-documented outbreak in North America during the early 1970s, as

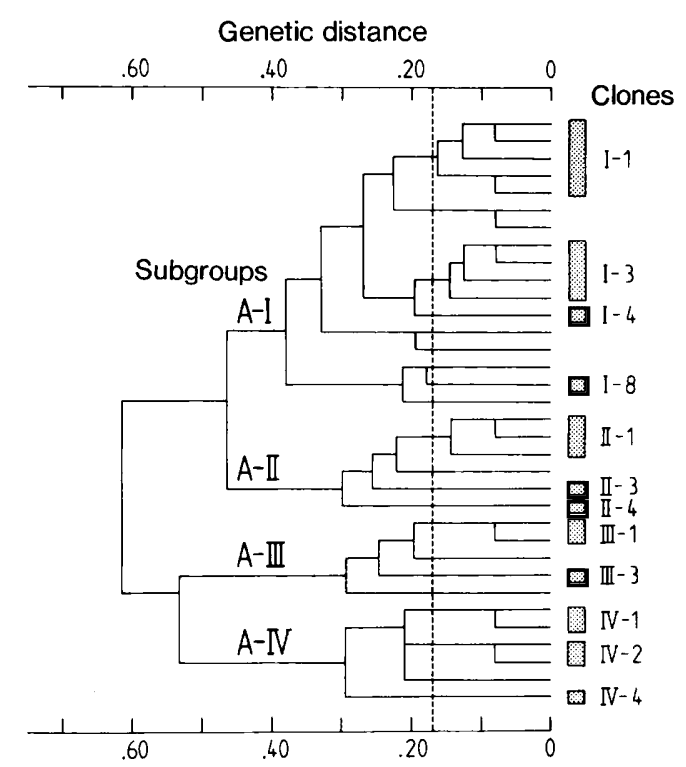

Fig. 8. Dendrogram showing a cluster analysis of 34 serogroupA electrophoretic types. The results represent the variability found within 423 serogroup-A meningococci chosen from as diverse sources as possible. Thirty-four distinct electrophoretic types are indicated by the horizontal lines together with the genetic distance at which they subdivided. Four subgroups (A-1 -A-IV) could be distinguished and the electrophoretic types which split at a genetic distance $>0.17$ were assigned to one of 21 clones labelled I-1-IV-4 to indicate the subgroup and clonal grouping. Common clones isolated reproducibly from epidemics of the last 25 years are indicated at the right by the stippled boxes and clonal labels.

well as numerous cases not linked with epidemics in other continents. A second distinct pandemic caused by clone III-1 was first represented in our strain collection by isolates from Finland and Brazil from the mid-1970s and caused a later epidemic in Nepal (1983) as well as numerous cases in China (1984). Clone IV-1 has only been isolated from West Africa where it has been consistently isolated from cases between 1962 and 1985 and caused epidemics between 1981 and 1983.

Most epidemics seemed to be associated with a single clone and the same clone often gave rise to concurrent epidemics in neighbouring countries. However, a few epidemics yielded a minority of clonal types other than the predominant one, indicating that epidemics of mixed aetiology are possible. The data suggest (but are not extensive enough to prove) that such mixed aetiologies may reflect distinct foci.

The results of these analyses provide a definitive typing scheme for serogroup-A meningococci which assigns certain clones to numerous former epidemics and which can readily be extended if 
new clones should be isolated in the future. More recent analyses have been performed in collaboration with J. T. Poolman and H. Abdillahi to identify monoclonal typing and sub-typing antibodies which correlate with the clonal analysis to allow rapid reliable typing. All serogroup-A strains are type 4 (Abdillahi et al., in press) and a panel of subtyping monoclonal antibodies (McAbs) which correlate with the SDS-PAGE assignments of class-1 protein migration is being developed (see Crowe et al., this review). LPS typing distinguished variants within epidemics which were common to other unrelated epidemics, but did not yield any obvious epidemiological meaning and could not readily be interpreted.

We have also begun a detailed analysis (Crowe et al., unpublished observations) in collaboration with B. Greenwood, R. Wall and M. Hassan-King of the Medical Research Council (Fajara, The Gambia) of one epidemic which occurred in The Gambia between 1982 and 1983 (Greenwood et al., 1987; see Wall, this review). Over 300 serogroup-A strains were isolated from the cerebrospinal fluid, blood or nasopharyngeal swabbings from patients, or from nasopharyngeal swabbings from healthy carriers. The bacteria were isolated during the epidemic (1982-1983) and for 2 years (1984-1985) after the effective immunisation in The Gambia performed at the end of 1983. Many of the carrier isolates were from patients swabbed three times sequentially within 2 months during the 1983 epidemic peak. The strains were passaged in the laboratory no more than three times before multiple single colonies were isolated, stored on multiple glass beads at $-70^{\circ} \mathrm{C}$, and outer-membrane preparations made. A set of 64 representative strains was chosen for a detailed analysis and these were compared with an additional 27 non-serogroup-A meningococci which were also isolated from the nasopharyngeal swabbings of healthy carriers.

A clonal analysis performed as above assigned all 64 serogroup-A strains to clone IV-1 whereas the non-serogroup- $A$ strains were assigned to various new clones which differed with the serogroup (Y, 29E, W-135, non-groupable). All further analyses were performed only with the serogroupA isolates. SDS-PAGE revealed that the clone IV1 isolates were not identical. Rare variants during the epidemic expressed very little class-1 protein (fig. 9), while by 1985, almost all the case isolates but none of the carrier isolates were of this formerly rare phenotype. Furthermore, migration on SDSPAGE of the class-5 proteins and pili differed from strain to strain. Thus these bacteria possessed stable clonal properties and variable strain properties. A number of other tests were conducted to see which other properties might be clonal and which variable.

LPS migration on SDS-PAGE proved to be clonal in these strains (63 of 64 strains synthesised L9 LPS); all other clone IV-1 strains isolated outside The Gambia between 1962 and 1983 proved to express the same LPS. We note that, as suggested above, this is not generally true. Distinct LPS types were detected within clone I-1 and clone III-1, even when strains from one country and one year were compared.

DNA restriction endonuclease fingerprinting revealed only five patterns with minor differences within the 64 strains tested whereas 14 distinct patterns were found among 34 strains representative of the 34 different serogroup-A electrophoretic types (Olyhoek et al., 1988). Four of the five Gambian patterns were found for one strain each and one of these strains was found to possess a 15$\mathrm{kb}$ plasmid. No plasmid could be detected in the other Gambian serogroup-A strains tested. However, sulphonamide resistance varied dramatically between the strains, with MIC values ranging from $<0.25$ to $>64 \mu \mathrm{g} / \mathrm{ml}$.

As mentioned above, the class -5 protein pattern differed from strain to strain. To analyse this phenomenon, all the (over 750) sub-colonies derived from the 317 case and carrier strains from The Gambia were examined. A total of five distinct class-5 proteins, labelled "a"-"e" could be detected by SDS-PAGE with $3 \mathrm{M}$ and $4 \mathrm{M}$ urea (see below). Almost all strains possessed at least one class-5 protein and "a", "b", "c" and "d" were each found in $23-60 \%$ of the strains whereas " $e$ " was found in only $3 \%$. Individual colonies expressed between zero and four class- 5 proteins. Variation in these proteins was found in the laboratory during passage and it is impossible to deduce the original class-5 composition of the one-third of the strains whose sub-colonies were not uniform. However, comparison of the remainder revealed that isolates taken from different sites of any one patient (CSF vs. blood vs. nasopharyngeal swab) varied for many patients and that nasopharyngeal swabs taken over a period of 2 months from healthy carriers also yielded variants. So far, no unique association of any one protein was detected with any clinical disease state. Thus, we conclude as have others (Poolman et al., 1980; Tinsley and Heckels, 1986) that the class- 5 proteins can vary within the body although the reason for this variation remains unclear. All the membrane preparations were also tested by Western blotting with monoclonal SM1 (Virji and Heckels, 1983; Virji et al., 1983; Heckels and Virji, 1985) antibodies (from J. Heckels) and 


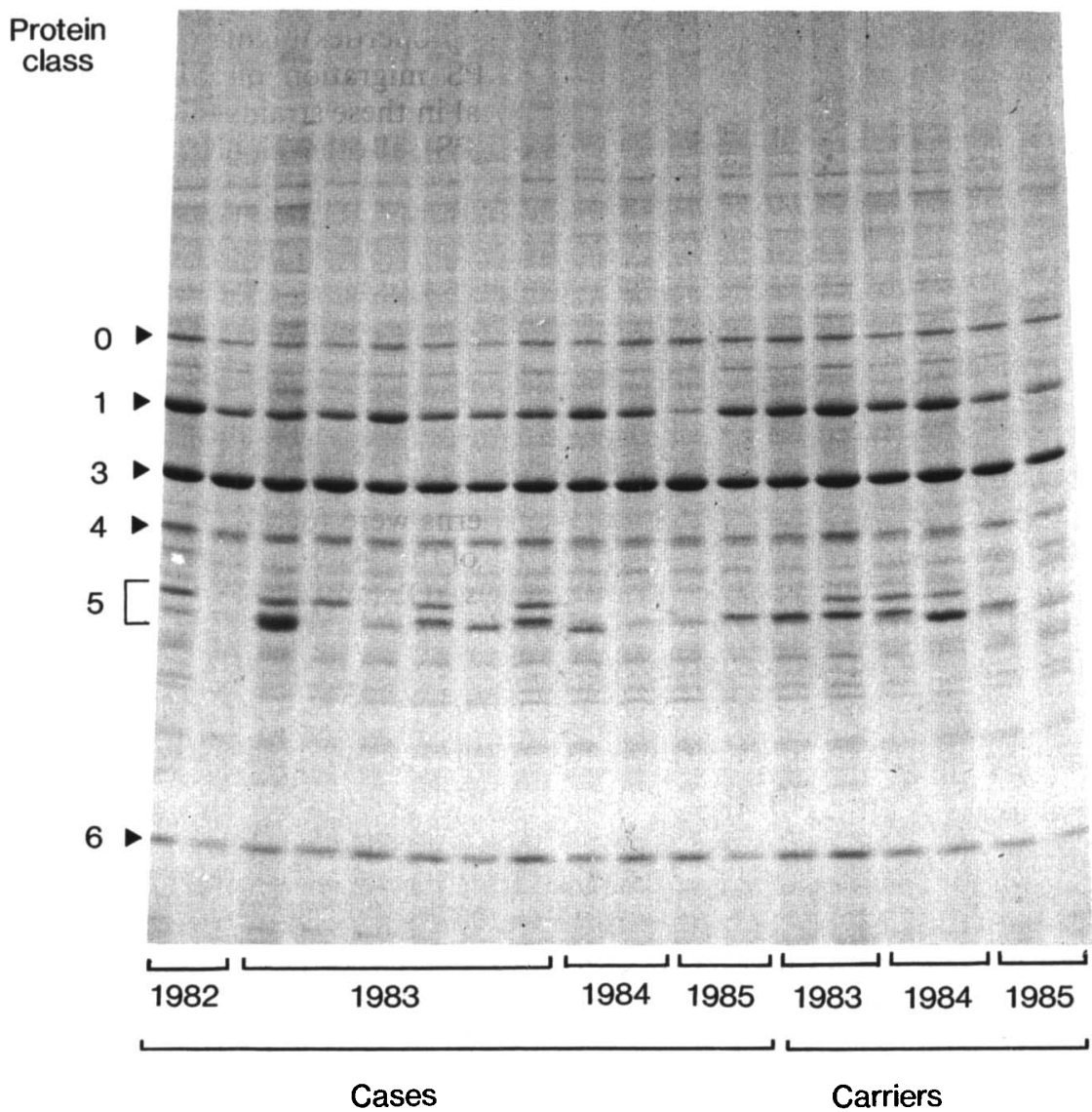

Fig. 9. Outer-membrane profiles of Gambian serogroup-A epidemic (1982-83) and post-epidemic (1984-85) isolates. A selection of case and carrier strains isolated during the indicated years is shown. The positions of the proteins of classes $0,1,3,4,5$ and 6 are indicated. The leftmost of the two case isolates from 1985 was scored as possessing diminished class-1 protein.

sub-colonies derived from $90 \%$ of the strains gave positive reactions. Thus clone IV -1 in The Gambia possessed SM1 pili. However, the pilus migration varied between sub-colonies derived from a common strain as documented by Tinsley and Heckels (1986), indicating that the variation which occurred during passage in the laboratory was so extreme that no conclusions can be reached about the variation in the body.

Numerous Gambian serogroup-A strains were also tested for sensitivity to the bactericidal effects of $20 \%$ human complement supplemented with monoclonal anti-class 1 or anti-LPS antibodies (obtained from J. Poolman) or with hyper-immune rabbit serum raised against live Gambian bacteria. Generally, the bacteria were killed when the antibodies were added at dilutions from 40 to 1000 whereas they survived in control tests containing heat-inactivated complement or complement in the absence of additional antibodies (the complement was from a rare healthy volunteer whose serum did not kill serogroup-A strains at concentrations up to $50 \%$ ). However, some of the serogroup- $\mathrm{A}$ isolates from The Gambia were resistant to antibodymediated complement killing stimulated by one or all of these antibodies. During the epidemic peak season, 17 strains with diminished class-1 protein15 from carriers $(8 \%$ of all carrier isolates) and 2 from cases (3\% of all case isolates) -were isolated. All were resistant to killing stimulated by the anticlass 1 McAbs but sensitive to killing stimulated by the other antibodies. One carrier isolate of the 29 case and carrier isolates tested from this period, with normal amounts of class- 1 protein, was also resistant to the anti-class $1 \mathrm{McAbs}$. None of these strains were resistant to the other antibodies. After the immunisation campaign, only limited numbers of case and carrier strains were isolated. Within the first year, one of the 15 carrier strains was diminished in class-1 protein and resistant only to 
the anti-class $1 \mathrm{McAb}$, and a second strain produced normal amounts of class- 1 protein and was resistant to the hyper-immune rabbit serum only. None of the seven case isolates from that period expressed diminished amounts of class- 1 protein but one was resistant to the anti-class $1 \mathrm{McAb}$ and a second synthesised a different LPS and was resistant to all three antibodies. During the subsequent year, all the 10 carrier isolates came from one epidemiological source and all were sensitive to killing. Four of the six case isolates expressed diminished amounts of class-1 protein and were resistant to killing by all three antibodies. We conclude that the expression of diminished amounts of class-1 protein apparently results only in resistance to the anti-class 1 antibodies. Furthermore, apparently homologous serogroup-A strains can differ in resistance to antibody-mediated killing. Finally, the results are consistent with the immunisation campaign having selected among the case isolates for serogroup-A strains that were generally resistant to antibodymediated complement killing and were also diminished for unknown reasons in class-1 protein. We have no information yet on the molecular mechanism that can lead to complement resistance. Recent observations with 23 representative serogroup-A bacteria from our international collection (W. Opferkuch, personal communication) revealed that half of these latter strains were also at least partially resistant to bactericidal activity and possessed diminished amounts of class-1 protein.

Although the strains isolated during the 19821983 Gambian epidemic were sensitive to bactericidal activity, numerous sera from healthy individuals as well as from the early acute phase of disease possessed bactericidal activity (Greenwood et al., 1987). Our experiments showed that such bactericidal activity was often type-specific, killing one generally sensitive Gambian strain but not another. Thus we began an analysis of the epitopes on the bacterial cell surface of sensitive strains which can be responsible for type-specific bactericidal killing. Because only limited amounts of the Gambian sera are available, initial experiments were performed with 30 random human sera available in larger quantities, half taken before the epidemic from Gambian patients with diseases unrelated to meningitis and half obtained from geriatric patients or healthy volunteers in Berlin. Bactericidal tests showed that only 2 of the 30 sera could kill all Gambian strains, half of the sera had very low or no bactericidal titres and the remainder were typespecific (Slawig, 1986). Two of the type-specific sera were chosen for detailed analysis. The pattern of killing correlated strongly with the class-5 protein, one serum killing strains possessing "c" protein and the other killing strains possessing " $b$ " or " $d$ " proteins. However, no correlation was found between this biological activity and the antigen specificity demonstrated by Western blotting. Experiments were performed with hyper-immune rabbit sera. Rabbits were given intravenous injections of live Gambian bacteria possessing different class- 5 proteins. When analysed by Western blotting, most of the detectable antibodies were directed against the class- 5 proteins, except that no antibodies were seen against class-5 variant "c". Selective adsorption with Gambian strains lacking the "a" or lacking the " $b$ " and " $d$ " proteins resulted in mono-specific sera that killed only strains possessing " $a$ " or strains possessing " $b$ " or " $d$ " (or both) proteins, respectively. In Western blots, these mono-specific sera reacted only with the " $a$ " or the "b" or "d" (or both) proteins, respectively. A monospecific anti-"c" serum was made by immunising rabbits with purified protein plus Freund's complete and incomplete adjuvant. This serum reacted in Western blots with variant "c" but was not bactericidal. Recently, McAbs that demonstrate the above specificities in Western blots (anti"a", anti-"c" or anti-"b" or "d") have been isolated (Achtman et al., in press).

Because the type-specific human sera did not react in Western blots, their specificity was analysed by selecting bacterial mutants resistant to the individual sera. Such mutants arose at high frequency (several percent of the original population) and were totally resistant to the homologous serum but still sensitive to other sera. On analysis, the mutants were found to lack specific class- 5 proteins and, for one serum, also to lack pili. Thus, it seems as if type-specific bactericidal activity in human sera may be directed against class-5 proteins or SM1 pili or both.

To analyse the sera in more detail, methods were developed (Achtman et al., in press) to purify each of the five class-5 proteins "a", "b", "c", "d", and "e". Three additional class-5 proteins called " $\mathrm{f}$ ", " $g$ " and " $h$ " from clone IV-1 strains isolated outside The Gambia were also purified. The methods yield $10-20 \mathrm{mg}$ of purified protein after 2 days of work with no significant contamination with capsule, DNA, LPS or other proteins. N-terminal amino acid sequencing revealed that all the proteins except "c" possess an N-terminal sequence almost identical to that of two opr genes sequenced from $N$. meningitidis serogroup C (Stern and Meyer, 1987). The N-terminal sequence also contains most of the consensus sequence based on 10 gonococcal P.II proteins and opa genes (Barritt et al., 1987). The 


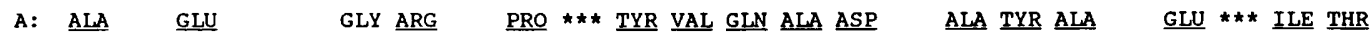

B: ALA SER GLU ASP GLY SER ARG SER PRO TYR TYR VAL GLN ALA ASP LEU ALA TYR ALA ALA GLU ARG ILE THR HIS ASP

C: ALA GLN GLU LEU GLN THR ALA ASN GLU PHE THR VAL HIS THR ASP LEU ( ) ( ) ILE VAL

5

10

15

20

25

Fig. 10. N-terminal amino-acid sequences of P.II and class-5 proteins. (A) consensus sequence of P.II proteins according to Barritt et al. (1987). The amino acids which are also common to meningococci are underlined. The two sets of *** represent single amino acid insertions necessary for the meningococcal sequences to fit the gonococcal consensus sequence. (B) N-terminal sequence of seven class-5 proteins from serogroup A clone IV-1 (Achtman et al., 1988) and two serogroup-C proteins (Stern and Meyer, 1987). The only differences were for two proteins at position 5 . The underlined amino acids are the only ones which appear in class-5 protein c. (C) N-terminal amino acid sequence of class-5 protein $\mathrm{c}$ from two different Gambian serogroup-A strains. The same amino acids are underlined as in part $\mathbf{B}$

"c" protein differed from the others (fig. 10). Furthermore, broad-range cross-reacting McAbs directed against gonococcal P.II proteins (4B12C11; obtained from $M$. Blake) reacted with "a", "b", "d", "e", "f", "g" and "h" proteins but not with "c". The "c" protein is not unique to Gambian strains. Western blotting with the anti"c" (M306) and the broad-range McAbs revealed that all class- 5 proteins detectable by Coomassie blue staining of SDS-PAGE gels of membranes from 70 diverse serogroup-A strains reacted either with the broad range McAbs (67 protein bands) or with the anti-c McAb (39 bands) but not with both. The purified proteins are now being used in ELISA tests to determine the correlation between human antibodies and bactericidal killing. The initial results demonstrate that the class-5 proteins are highly immunogenic in healthy carriers and that high antibody levels are demonstrable in sera with high bactericidal titres.

In summary, a clonal analysis has been performed, which allows typing of all serogroup-A meningococci and showed that most epidemics were predominantly caused by a single clone. The recognition of concurrent epidemics caused by the same clone has allowed the retrospective recognition of two distinct pandemics. Furthermore, a clone such as IV-1 may cause cases in a large geographical area for decades and be involved in more than one epidemic wave. A detailed analysis of case and carrier strains isolated during and after the 1982-1983 epidemic in The Gambia revealed that all the serogroup-A bacteria, whether isolated from cases or carriers, belonged to clone IV-1 while serogroup $\mathrm{Y}, 29 \mathrm{E}$ and $\mathrm{W}-135$ bacteria belonged to unrelated serogroup-specific clones. The clone IV1 bacteria were uniform in LPS and DNA fingerprint but varied in other properties, namely migration of SM1 pili, expression of the class-5 proteins "a", "b", "c", "d" and "e" and quantitative expression of the class-1 protein. Finally, some of the bacteria isolated from Gambian patients after the 1983 immunisation campaign were resistant to bactericidal killing suggesting that the immunisation may have selected for such strains. Analysis of human sera revealed that most bactericidal activity was type-specific and apparently directed against individual class- 5 proteins or SM1 pili or both. Bacterial survivors were easy to isolate from the bactericidal tests, had lost the respective antigen(s) and were totally resistant to killing by the homologous serum. The different class -5 proteins have been purified and found to fall into three serological groups ("a"; "b", "d" and "e"; "c"), as defined both by hyper-immune sera and McAbs, and two protein subclasses ("a", "b", “d", "e", "f", "g", "h" v. "c"). Both class-5 proteins subclasses are common among all serogroup-A strains.

\section{Typing of group-B Neisseria men- ingitidis with monoclonal antibod- ies in the whole-cell ELISA}

\section{H. ABDILLAHI and J. T. POOLMAN}

National Institute of Public Health and Environmental Hygiene, Bilthoven, The Netherlands

The surface antigens of Neisseria meningitidis vary in composition in different isolates. It is important, for epidemiology, to know which variant antigens are expressed on which isolates. Knowledge about the relationship of such antigens to pathogenic effects and to the induction of protective immunity is important for the development of vaccines. The antigens are defined by serological reactions with polyclonal or monoclonal reagents and are classified according to the molecules which bear them. Serotypes are defined by reactions with antigenic determinants on an outer-membrane 
macromolecular complex that includes outer-membrane protein (OMP) 2/3. Subtyping is according to the reactions with OMP 1 (Frasch et al., 1985a). Since the latter OMP has been shown to be related to the induction of protective responses in experimental animals (Saukkonen et al., 1987) and since antibodies to this OMP are bactericidal (Mocca $e t$ al., 1984; Poolman et al., 1985), it is the most likely candidate antigen for a vaccine.

Group-B meningococci are the most common cause of meningitis in industrialised countries and there is not yet a vaccine against it (Poolman et al., 1986). A first step towards the identification of antigens which must be included in a vaccine is to identify those types or subtypes most frequently associated with infection. When we began these studies, only about $30 \%$ of the isolated strains were typable and about $50 \%$ could be assigned a subtype (nearly always P1.2, P1.9, Pl.15 or Pl.16). This inadequate record was due to the lack of specific reagents for typing. One obvious approach to the solution of this problem was to make monoclonal antibodies (McAbs). We first prepared SDS-PAGE profiles of the OMPs of a large collection of nontypable strains. We sorted these into groups with common patterns and used these pooled strain "cocktails" to immunise mice for the production of McAbs. The McAbs obtained were tested first in an ELISA, with plates coated with OMPs from the individual strains. The hybridomas producing antibodies interesting for their specificity were cloned and expanded; the antibodies were further investigated to determine the molecule they recognised by gel-immuno-radio-assay (GIRA) (Poolman and Buchanan, 1983). The most promising clones were injected into Pristane-primed mice for the production of ascites containing high concentrations of immunoglobulins.

The monoclonal antibodies thus prepared were employed in a new test, the whole-cell ELISA (WCE) (Abdillahi and Poolman, 1987). In this test, the bacteria to be screened were coated intact on to the microtitration plates by evaporation at $37^{\circ} \mathrm{C}$. After incubation with the McAbs, binding was revealed by peroxidase-labelled protein $A$ and 3,3',5,5'-tetramethyl-benzidine (TMB) as substrate. This new technique could discriminate clearly between strains carrying the antigens recognised specifically by the McAbs, and those which did not.

Using this technique, we have sero- and subtyped 247 isolates of group-B $N$. meningitidis from 19 countries, most of which had been submitted to us as non-typable. The results of the serotyping of the 247 strains, with $12 \mathrm{McAbs}$ are shown in table II. It can be seen that $75.7 \%$ of the strains could be serotyped, which is a considerable improvement over the earlier results (Abdillahi et al., 1986). This is mainly due to the addition to the typing panel of

Table II. Results of serotyping with whole-cell ELISA and McAbs

\begin{tabular}{|c|c|c|c|c|c|c|c|c|c|c|}
\hline \multirow{2}{*}{$\begin{array}{l}\text { Country } \\
\text { of origin }\end{array}$} & \multicolumn{9}{|c|}{ Number of strains of serotype } & \multirow[b]{2}{*}{ Total } \\
\hline & 1 & $2 a$ & $2 \mathrm{~b}$ & 4 & 11 & 14 & 15 & 16 & NT & \\
\hline Australia & 1 & 1 & & 1 & & 1 & 2 & & 4 & 10 \\
\hline Austria & & & 1 & 1 & & & & & 4 & 6 \\
\hline Belgium & & 2 & 1 & 1 & & & & & 2 & 6 \\
\hline Canada & & & & 1 & & & 1 & 4 & & 6 \\
\hline Chile & & & & & & & 1 & & & 1 \\
\hline China & & & 1 & & & & 1 & & 1 & 3 \\
\hline Cuba & & & & 7 & & & & & & 7 \\
\hline Denmark/Faroe & 2 & & & 6 & 1 & 2 & 6 & 2 & 21 & 40 \\
\hline England & & 1 & & 6 & & 1 & & 1 & & 9 \\
\hline Finland & & & & 2 & & 3 & & 1 & 2 & 8 \\
\hline France & & 4 & & 13 & & 2 & & & 3 & 22 \\
\hline Germany & & & & 8 & & 1 & & & 6 & 15 \\
\hline Hong Kong & & 2 & & & & & & & 5 & 7 \\
\hline Iceland & & & & 2 & 1 & & 1 & & 1 & 5 \\
\hline Netherlands & 4 & 3 & & 16 & 2 & 6 & 18 & 4 & 8 & 61 \\
\hline Norway & 1 & & & 1 & 1 & & 1 & & 1 & 5 \\
\hline Spain & & & 2 & 3 & & & 3 & & 1 & 9 \\
\hline Switzerland & & & & 16 & & 1 & & & & 17 \\
\hline USA & 1 & & 3 & 3 & & & 2 & & 1 & 10 \\
\hline All & $\begin{array}{c}9 \\
(3.6 \%)\end{array}$ & $\begin{array}{c}13 \\
(5 \cdot 3 \%)\end{array}$ & $\begin{array}{c}8 \\
(3 \cdot 2 \%)\end{array}$ & $\begin{array}{c}87 \\
(35 \cdot 2 \%)\end{array}$ & $\begin{array}{c}5 \\
(2 \cdot 0 \%)\end{array}$ & $\begin{array}{c}17 \\
(6.8 \%)\end{array}$ & $\begin{array}{c}36 \\
(14 \cdot 6 \%)\end{array}$ & $\begin{array}{c}12 \\
(4 \cdot 9 \%)\end{array}$ & $\begin{array}{c}60 \\
(24 \cdot 3 \%)\end{array}$ & $\begin{array}{c}247 \\
(100 \%)\end{array}$ \\
\hline
\end{tabular}


McAbs able to identify serotype 4 (Abdillahi et al., in press) with some contribution from the anti-16 and anti-11. Also, our new anti-serotype 15 (MN15.A14.H6) McAb seems to cover a broader range of type 15 antigens, because it identifies more of these types than did the older anti-15 McAbs.

In table III are given the results of the subtyping with a panel of 12 subtyping McAbs. The proportion which could be subtyped was $81.4 \%$; this is also better than the $50 \%$ of earlier work (Abdillahi et al., 1986). The McAbs against Pl.1, P1.1, 16 and P1.6 were major contributors to this improvement. A new category arose through the recognition by two McAbs of many strains of types Pl.1 or Pl.16 or both; quite a few strains, however, were recognised only by these two antibodies and not by those against $\mathrm{Pl} .1$ or $\mathrm{Pl} .16$ separately, and these are listed on the table as Pl.1,16. For both Pl.15 and Pl.16, two new McAbs were used for subtyping; this seems to have improved the success rate.

Most reports on the relationships between serotype and disease could not take into account the large proportion of non-typable strains. Furthermore, the rate of success in subtyping did not usually permit a consideration of the possible association between subtype and disease. Considering serotyping and subtyping together, with this rapid, sensitive and reproducible whole-cell ELISA and highly specific McAbs, the great majority (236 of $247 ; 95.5 \%$ ) of our collection of previously nontypable strains of group-B meningococci could be identified. This illustrates the usefulness of subtyping, in addition to serotyping, for following the spread of meningococci within and between countries and for studying the relationships between the different antigenic types and the patterns of disease. Now that better tools are available, we may be better able to do this. We are confident that with the addition of new McAbs to our panel, the goal of making a complete sero-subtyping kit is within reach.

Clonal typing schemes for meningococci have recently been developed based on the clonal population structure of these organisms (Olyhoek et al., 1985). These methods are capable of distinguishing strains of different epidemic foci from different epidemic situations and have shown the occurrence of a number of major epidemic waves. Clonal analyses have not been found to correlate with serotyping results amongst group-B and -C meningococci (Caugant et al., 1987); however, subtyping results with group-A strains (B. Crowe et al., this review) show a clear correlation with clonal analyses. It would be informative to compare clonal typing with subtyping results obtained with our improved technique.

Table III. Results of subtyping with whole-cell ELISA and McAbs

\begin{tabular}{|c|c|c|c|c|c|c|c|c|c|}
\hline \multirow{2}{*}{$\begin{array}{l}\text { Country } \\
\text { of origin }\end{array}$} & \multicolumn{8}{|c|}{ Number of strains of subtype } & \multirow[b]{2}{*}{ Total } \\
\hline & Pl.1 & P1.1,16 & P1.2 & P1.6 & P1.9 & P1.15 & $\mathrm{P} 1.16$ & NT & \\
\hline Australia & 2 & & & & 5 & & & 3 & 10 \\
\hline Austria & & & 2 & 3 & & & & 1 & 6 \\
\hline Belgium & & & 3 & & 1 & & 1 & 1 & 6 \\
\hline Canada & & & & & & & 1 & 5 & 6 \\
\hline Chile & & 1 & & & & & & & 1 \\
\hline China & & & 3 & & & & & 0 & 3 \\
\hline Cuba & & & & & & 7 & & & 7 \\
\hline Denmark/Faroe & 2 & & 2 & 2 & 11 & 5 & 14 & 4 & 40 \\
\hline England & 2 & 1 & & & & 4 & & 2 & 9 \\
\hline Finland & & 2 & 1 & 1 & & 1 & 2 & 1 & 8 \\
\hline France & 1 & & 3 & & & 10 & & 8 & 22 \\
\hline Germany & 2 & & 4 & 1 & 1 & 2 & & 5 & 15 \\
\hline Hong Kong & & & 4 & & & & & 3 & 7 \\
\hline Iceland & 1 & & & 1 & 2 & & & 1 & 5 \\
\hline Netherlands & 4 & 16 & 5 & 3 & 2 & 9 & 16 & 9 & 61 \\
\hline Norway & 1 & & & & & 1 & 1 & 2 & 5 \\
\hline Spain & 1 & & 2 & 2 & & 1 & 3 & & 9 \\
\hline Switzerland & & & & & & 17 & & & 17 \\
\hline USA & 1 & 1 & 4 & & & 1 & 2 & 1 & 10 \\
\hline All & $\begin{array}{c}17 \\
(6 \cdot 9 \%)\end{array}$ & $\begin{array}{c}21 \\
(8.5 \%)\end{array}$ & $\begin{array}{c}33 \\
(13.4 \%)\end{array}$ & $\begin{array}{c}13 \\
(5 \cdot 3 \%)\end{array}$ & $\begin{array}{c}22 \\
(8.9 \%)\end{array}$ & $\begin{array}{c}58 \\
(23.5 \%)\end{array}$ & $\begin{array}{c}37 \\
(14.9 \%)\end{array}$ & $\begin{array}{c}46 \\
(18.6 \%)\end{array}$ & $\begin{array}{c}247 \\
(100 \%)\end{array}$ \\
\hline
\end{tabular}


Before progress can be made in the development of a vaccine, it is necessary to identify molecules on the surface of the bacteria which may be good targets for protective immune responses and which can induce such responses. It is, therefore, of great interest to analyse and identify as completely as possible the data of sero-subtyping results of more isolates of meningococci from more countries, with the aim of establishing which outer-membrane proteins might be essential in a vaccine against meningitis caused by group-B meningococci.

\section{Molecular cloning and expression of Neisseria meningitidis class 1 outer-membrane protein in Esch- erichia coli K-12}

ANN K. BARLOW, J. E. HECKELS and I. N. CLARKE

Department of Microbiology, University of Southampton Medical School, Southampton General Hospital, Tremona Road, Southampton SO9 $4 X Y$

Surface antigens of the meningococcus participate in host-bacterial interactions such as colonisation of mucosal surfaces, uptake by epithelial cells and interaction with host defences, the results of which determine the outcome of meningococcal acquisition. Meningococcal infection or carriage elicits protective, bactericidal antibodies directed against surface antigens, such as the polysaccharide capsule and outer-membrane proteins (OMPs). Vaccination with these surface antigens is, therefore, an attractive strategy for immunisation against meningococcal disease. Purified capsular polysaccharide vaccines are available (Hankins et al., 1982); however, these vaccines are poorly immunogenic in young children (Käyhty et al., 1980) and the polysaccharide of group-B meningococci, an important cause of meningococcal disease in many Western countries, is non-immunogenic even in adults. Hence, attention has focused on the surface proteins of the meningococcus in an attempt to determine their potential for inclusion in new or improved anti-meningococcal vaccines.

It has been shown previously (Tinsley et al., 1986) that two of the major surface proteins of the meningococcus-pili and class-5 OMPs - undergo antigenic shifts, which may permit the bacteria to evade the consequences of the immune response during the course of infection, and may well explain the persistence of nasopharyngeal carriage despite the presence of a host immune response. The quantitatively major OMP (class- 2 or -3 protein) is not subject to antigenic shift but differs between strains and is the basis of the serotype classification of meningococci (Frasch et al., 1985). Antigenic heterogeneity poses considerable problems for vaccine development and focuses attention on surface proteins which are more conserved between strains and which may elicit a protective immune response. One such candidate is the class-1 OMP (Tsai et al., 1981).

Although the class- 1 protein may be responsible for serological differences between strains (Poolman et al., 1980), it shows less variation than other surface proteins (Zollinger et al., 1984). An antiserum raised against the purified class-1 protein reacts with a wide variety of different strains, suggesting that there are highly conserved domains within different class-1 proteins (Dr B. Crowe, personal communication; J. E. Heckels, unpublished observations). The bactericidal activity of serum, after immunisation with a complex of polysaccharide and outer-membrane complex (OMC), appears to be related to the presence of a high IgG response to the class-1 protein which consists primarily of those IgG subclasses important in complement activation and opsonisation (Wedege et al., 1987). The class-1 OMP is, therefore, an attractive potential target antigen for vaccination but little is known about its function in the meningococcus or its antigenic structure.

We have begun to investigate the potential for cloning OMPs in Escherichia coli to investigate their structure in greater detail, and to obtain adequate amounts of purified proteins for immunological studies.

OMC was prepared from a clinical isolate of Neisseria meningitidis (MC50), obtained from the Public Health Laboratory at Southampton General Hospital, and was used to immunise rabbits to obtain a polyclonal anti-OMC serum. This serum reacted with the class $-1,-2,-4$ and -5 OMPs of MC50 as well as with the pathogenic neisseria antigen (H8 antigen) in Western blots (Barlow et al., 1987).

Meningococcal DNA from the same strain was prepared (Tinsley et al., 1986) and digested with the restriction enzyme $E c o$ R 1 . The fragments were ligated into EcoR1-cut, dephosphorylated $\lambda \mathrm{GT} 11$ DNA (Promega Biotec), packaged in vitro (Maniatis et al., 1982), and plated on to E. coli strain Y1090 $\mathrm{r}$ - (Promega Biotec). Approximately $10000 \mathrm{pfu} /$ $\mu \mathrm{g}$ of DNA were obtained; $87 \%$ of plaques were white on plates containing IPTG and X-gal, indicating insertional inactivation of the vector $\beta$ galactosidase gene. This recombinant library was amplified to obtain a high-titre stock and screened 
with the polyclonal anti-OMC serum, which had been previously absorbed with an $E$. coli- $\lambda \mathrm{GT} 11$ lysate to remove antibodies directed against, or cross-reacting with, $E$. coli or phage proteins (Barlow et al., 1987). Expressing plaques were picked and purified to homogeneity by re-plating and re-screening to obtain single reactive plaques. Seven recombinants were chosen and amplified to obtain high-titre stocks. Restriction analysis of all seven recombinants showed them to be identical (as might be expected from a non-random, amplified library), and one recombinant $(\lambda \mathrm{Al})$, was chosen for further analysis.

Expression of the immunological product in $\lambda \mathrm{A} 1$ plaques as detected by the polyclonal anti-OMC serum was shown to be increased in the presence of IPTG and, therefore, under the inducible control of the $\beta$-galactosidase promoter, showing that the native, meningococcal class- 1 gene promoter and amino-terminal sequences are absent in $\lambda \mathrm{Al}$.

The recombinant protein expressed by $\lambda \mathrm{Al}$ did not react with available monoclonal antibodies directed against pili (Virji et al., 1983) or the H8 antigen (Virji et al., 1985). Therefore, to identify which OMP was being expressed by $\lambda \mathrm{A} 1$, antibodies that recognised epitopes on the expressed protein were affinity purified from the polyclonal antiOMC serum (Barlow et al., 1987). Antibodies that bound specifically to IPTG-induced $\lambda \mathrm{Al}$ plaque proteins were eluted and used to probe Western blots of OMC from strain MC50. These specific antibodies appeared to react with the class-1 protein. To confirm this result, phage lysates, obtained from $\lambda A 1-$ recombinant and $\lambda$ GT11-control phage, together with meningococcal OMC from two strains that possess identical Mr class-1 proteins but different $\mathrm{Mr}$ class- 2 proteins, were separated by SDS-PAGE (fig. 11, panel a), and transferred to nitrocellulose by Western blotting. These blots were then probed with a polyclonal anti-class-1 protein serum, raised against gelpurified class-1 protein, (obtained from $\mathrm{Dr} \mathrm{B}$. Crowe, Max Planck Institute, Berlin) (fig. 11, panel b). This serum reacted with identical $\mathrm{Mr}$ bands in both meningococcal OMCs, confirming the specificity of the serum for the class-1 protein, and with a single high mol. wt band in the recombinant $\lambda \mathrm{Al}$ lysate track that was absent from the $\lambda \mathrm{GT} 11$ control. Antibodies from this anti-class-1 protein polyclonal serum were affinity purified with $\lambda \mathrm{Al}$ plaque proteins and used to probe similar tracks (fig. 11, panel c). These antibodies specifically bound by $\lambda \mathrm{A} 1$ recognised the class- 1 proteins in the meningococcal OMC. Thus, $\lambda \mathrm{A} 1$ was expressing epitopes present on the class-1 protein from MC50.

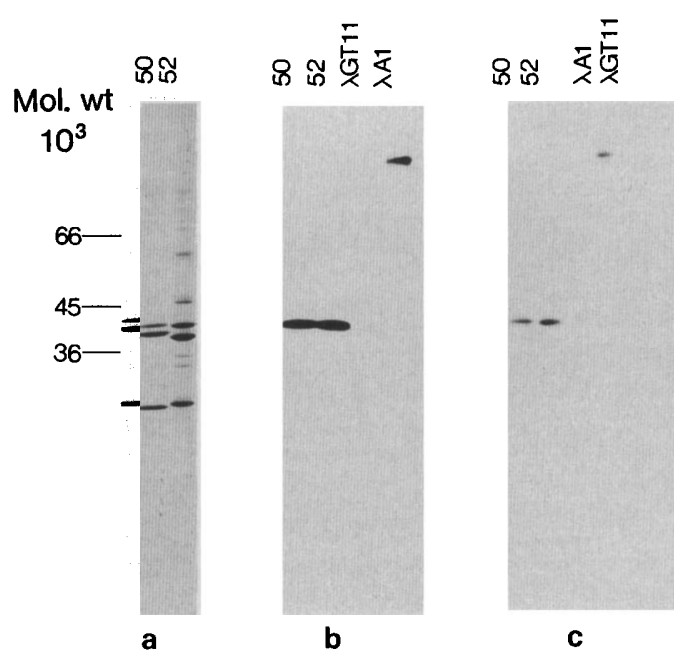

Fig. 11. $\lambda \mathrm{Al}$ is expressing MC50 class- 1 protein epitopes fused to $\beta$-galactosidase. Panel a: SDS-PAGE separated OMC from strains MC50 and MC52; the major proteins present in these preparations are high to low mol. wt - class 1, class 2 , class 4 (in relatively small amounts) and class 5 . These two strains possess similar class-1 proteins but different class- 2 proteins. Panel b: OMC from strains MC50 and MC52 and IPTG-induced phage lysates of $\lambda \mathrm{Al}$ and $\lambda \mathrm{GT} 11$, transferred to nitrocellulose and probed with a polyclonal anti-class-1 protein serum. Panel c: transferred proteins, as in panel $b$, probed with antibodies affinity purified from the anti-class-1 serum by $\lambda \mathrm{Al}$ plaque proteins. The serum reacts with only the class-1 OMPs from the two meningococcal isolates, and with a high mol.-wt band in the $\lambda \mathrm{Al}$ track (absent from the $\lambda \mathrm{GT} 11$ control). Antibodies affinity purified by $\lambda \mathrm{Al}$ react with the meningococcal class- 1 proteins.

To investigate how much of the class-1 structural gene was contained and being expressed in $\lambda \mathrm{A} 1$, a crude estimate of the size of the recombinant $\beta$ galactosidase protein was obtained by SDS-PAGE, with $7.5 \%$ polyacrylamide gels, run for $6 \mathrm{~h}$ to achieve greater separation of the higher mol. wt proteins (fig. 12, panel a). The identity of the putative fusion protein band in the $\lambda \mathrm{A} 1$ track was confirmed with an anti- $\beta$-galactosidase monoclonal antibody (Promega Biotec) (fig. 12, panel b). The $\beta$-galactosidase band (mol. wt $116 \times 10^{3}$ ) in the $\lambda$ GT11 lysate track was replaced by a band of mol. wt c. $156 \times 10^{3}$ in the $\lambda \mathrm{Al}$ lysate track, which also reacted with the anti-class-1 polyclonal serum (fig. 12 , panel c). A lower mol. wt breakdown product of $\beta$-galactosidase is present in $\lambda \mathrm{A} 1, \lambda \mathrm{GT} 11$ and $\beta$ galactosidase standard tracks; the intensity of this band in the recombinant track is increased, suggesting that the recombinant $\beta$-galactosidaseclass- 1 gene fusion protein is less stable than the native protein. The sizing data suggest that up to $40 \times 10^{3} \mathrm{~mol}$. wt of the class 1 protein may be fused to the $\beta$-galactosidase gene in $\lambda \mathrm{Al}$. 

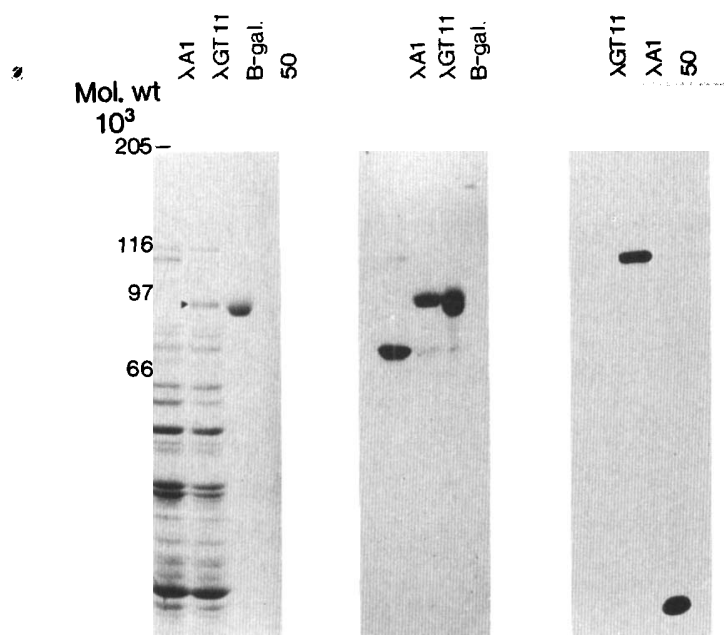

Fig. 12. Size estimation of the $\beta$-galactosidase-class 1 fusion protein. Panel a: the $\lambda$ GT11 vector $\beta$-galactosidase protein $(>)$ (mol.-wt. $116 \times 10^{3}$ ) comigrates with the $\beta$-galactosidase standard; this band is absent from the $\lambda \mathrm{Al}$-recombinant track, and is replaced with a band of mol. wt c. $156 \times 10^{3}(>)$. Panel b: SDSPAGE separated proteins were transferred to nitrocellulose and probed with an anti- $\beta$-galactosidase monoclonal antibody (Promega Biotec). A high-mol.-wt. band is detected in the $\lambda \mathrm{Al}$ track only, and replaces the native $\beta$-galactosidase band at mol. wt. $116 \times 10^{3}$ in $\lambda$ GT11. A breakdown product of $\beta$-galactosidase is seen in all tracks and is of greater intensity in the $\lambda \mathrm{A} 1$ track, suggesting that the recombinant protein is less stable than the native protein. Panel c: the high-mol.-wt. band in the $\lambda \mathrm{A} 1 \mathrm{track}$ reacts with the anti-class 1 polyclonal serum, which also detects the class-1 protein from MC50 OMC which is just still present on this gel.

Phage DNA from $\lambda \mathrm{Al}$ was prepared (Barlow et al., 1987) and digested with EcoR1. The 3.4-kb insert liberated was re-cloned into plasmid pMTL20 (Chambers et al., 1986) and subjected to restriction endonuclease analysis. The orientation of the insert in the original $\lambda \mathrm{A} 1$ recombinant is shown in fig. 13 .

The EcoRl - Xbal fragment fused to the vector $\beta$ galactosidase gene is approximately $1.2 \mathrm{~kb}$ in length which is sufficient to encode for protein of mol. wt c. $40 \times 10^{3}$ and so probably contains all or most of the class- 1 protein-coding region expressed by $\lambda \mathrm{A} 1$. The EcoR1-Kpnl fragment in this coding region was used to probe Southern blots of meningococcal DNA from strain MC50. A single 2.2-kb Xbal fragment from the genomic DNA hybridised to this probe indicating that there was a single copy of the class-1 structural gene, which must have been contained within this $X b a 1$ fragment. The EcoR1$K p n 1$ probe from the MC50 class-1 gene also hybridised to similar sized, single $X b a 1$ fragments in several different meningococcal isolates including those of a different subtype (fig. 14).

Thus, a large proportion of the class- 1 protein from a clinical isolate of $N$. meningitidis has been cloned and expressed in $E$. coli. It appears that class 1 proteins in different meningococcal strains exhibit a large degree of immunological and DNA sequence homology. Comparative sequence data, from different meningococcal subtypes, will identify regions of the protein which are highly conserved and which may be surface exposed and immunogenic in man. It may be possible to use these regions as peptides, or expressed in E. coli as a "live" vaccine,

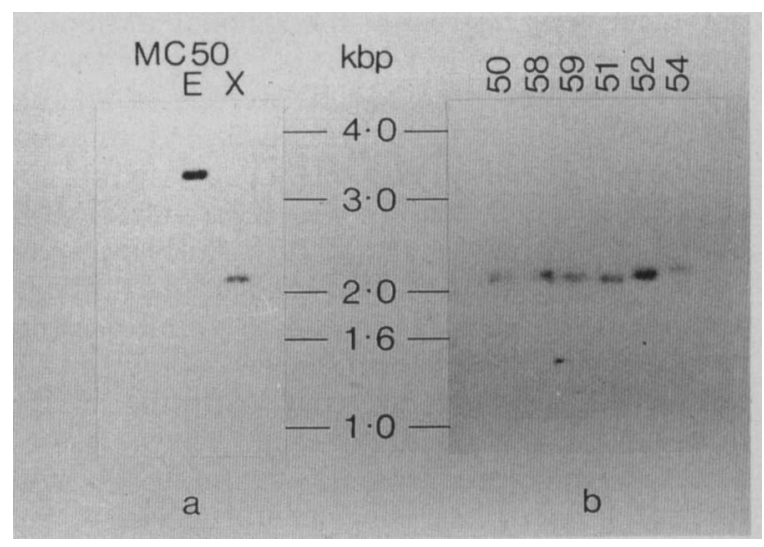

Fig. 14. The class- 1 gene is localised on a single $X b a 1$ fragment in meningococcal genomic DNA. Panel a: the EcoR1-Kpn1 fragment from the MC50 class- 1 gene hybridises to the expected 3.4-kb EcoR1 fragment in MC50 genomic DNA and to a single 2-2-kb Xbal fragment. Panel b: genomic DNA from different meningococcal strains was digested with $X b a 1$ and probed with the MC50 class-1 gene probe. Single $2 \cdot 2-\mathrm{kb} X b a 1$ fragments were detected in all strains tested, including at least one of different subtype. (Known subtype specificities-MC50, MC58, MC59, P1.16 and MC54 P1.3).

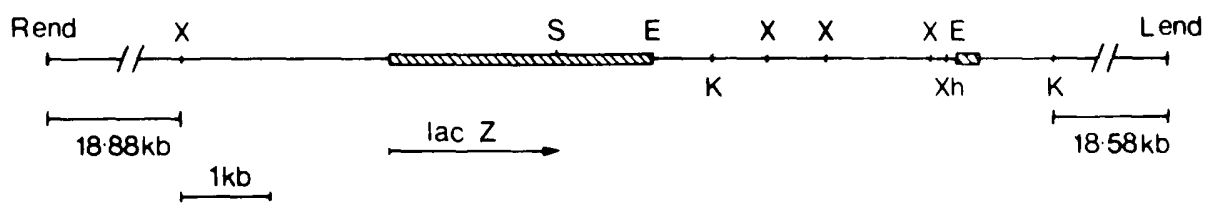

Fig. 13. Restriction endonuclease map of the $E c o \mathrm{R} 1$ insert in the original recombinant $\lambda \mathrm{A} 1$. Key: the direction of transcription of lac $\mathrm{Z}$ is indicated $\longrightarrow$ the $\beta$-galactosidase coding region 1 . The limits of the meningococcal insert are indicated by the $E c o \mathrm{R} 1$ sites (E). Other restriction sites are: $X b a 1(\mathrm{X}), X h o l(\mathrm{Xh}), K p n 1(\mathrm{~K})$ and $S s t 1(\mathrm{~S})$. The 1-2-kb EcoR1-Xbal region contains all or most of the coding region for the class-1 protein from strain MC50, expressed by $\lambda A 1$, and the EcoR $1-K p n 1$ fragment containing only protein coding regions was used as a hybridisation probe in Southern blots. 
in immunological studies. Information on the structure and control of expression of this surface antigen may be important in the further understanding of meningococcal pathogenesis.

Some of the work described above, including figs. 11-14, has been previously published in Infection and Immunity (Barlow et al., 1987).

\section{Correlation of serological typing and clonal typing methods for Neisseria meningitidis sero-group $A$}

B. A. CROWE, H. ABDILLAHI*, J. T. POOLMAN* and $M$. ACHTMAN

Max Planck Institut für molekulare Genetik, Ihnestrasse 73. D-1000 Berlin, West Germany and "National Institute of Public Health and Environmental Hygiene (RIVM) P.O. Box 1, 3720 BA Bilthoven, The Netherlands

For many years the epidemiology of meningococcal disease was primarily based on serogrouping the capsular polysaccharide antigens of the organism (Branham, 1953). This method provided extremely useful background information on the general epidemiology of meningococcal disease, showing that large epidemics of meningitis are almost exclusively associated with serogroup-A meningococci and that endemic disease is associated with serogroups B and C (Peltola, 1983). However, more refined typing methods are required for detailed epidemiological studies. Two such methods, clonal typing and the combination of monoclonal antibody (McAb) typing and subtyping, have recently been developed; these are capable of distinguishing between strains of the same serogroup and have provided additional insights into the epidemiology of meningococcal disease.

Clonal typing methods have now been used in epidemiological studies of serogroup-A meningococci (Olyhoek et al., 1987), and of other serogroups (Caugant et al., 1986a and b, 1987). The method is based on either the isoenzyme analysis of soluble cytoplasmic enzymes (Selander et al., 1987) or on a combination of isoenzyme analysis and outermembrane-protein analysis (Achtman and Pluschke, 1986). In the case of the clonal analysis of serogroup-A strains, the variations in seven cytoplasmic enzymes and the class- 1 and -6 outermembrane proteins were used (Olyhoek et al., 1987).
The McAb typing and subtyping methods were developed principally for the analysis of serogroupB strains (Frasch et al., 1985; Poolman et al., 1986; Abdillahi and Poolman, this review) and are based on the antigenic variation of the serotype antigen complex (a high-mol. wt complex often containing the class- 1 and -3 proteins and lipopolysaccharide) and the class-1 outer-membrane protein, respectively. The 12 typing and the 12 subtyping McAbs currently available, when used in a whole-cell ELISA technique (Abdillahi and Poolman, 1988), sufficed to serotype $75.7 \%$ and subtype $81.4 \%$ of serogroup-B strains (Abdillahi and Poolman, this review).

The typing and subtyping McAbs had not hitherto been used to screen serogroup-A strains and it was interesting to test these methods with this serogroup. A representative collection of 100 serogroup-A strains screened by the whole-cell ELISA with all typing and subtyping McAbs available to us. The collection included: representatives of all 21 clones and 34 distinct electrophoretic types (ETs; see fig. 2 Achtman et al., this review) resolved by the clonal analysis; representative strains from 23 serogroup-A epidemics that have occurred since $1960 ; 18$ strains each from two clones (clones I-1 and III-1) that caused worldwide pandemics between 1967 and 1975 and between 1973 and 1983, respectively; 20 strains from clone IV-1 which has been associated with three recent epidemic waves in West Africa (1960-63, 1967-73, and 1981-83); and 18 old strains isolated before 1950 in the USA and Britain (Olyhoek et al., 1987). These strains had formerly been shown to vary only marginally in respect to the class -3 protein, with two electrophoretic variants seen.

The 100 strains were screened with serotyping reagents specific for serotypes $1,2 \mathrm{a}, 2 \mathrm{~b}, 4,5,6,9$, $11,14,15$ and 16 (Abdillahi and Poolman, this review). Only those McAbs specific for serotype 4 were found to react with the serogroup-A strains but slightly different results were obtained with different anti-type $4 \mathrm{McAbs}$. All 100 strains reacted strongly with $\mathrm{McAb} \mathrm{MN}_{14} \mathrm{G}_{21.17}$ and 99 strains with $\mathrm{McAb} \mathrm{MN} \mathrm{MN}_{14} \mathrm{E}_{9.15}$ (Abdillahi et al., in press). The exceptional strain B435, a Scottish carrier strain, belongs to a clonal type with no other current representatives (clone II-2; Olyhoek et al., 1987) and has now been found to express a third electrophoretic variant of the class-3 protein (data not presented).

Seven different electrophoretic variants (designated 1-7) of the class-1 protein, the subtype antigen, were detected amongst serogroup-A strains (Olyhoek et al., 1987). The subtyping of the 
Table IV. Correlation between class-1 protein variant, subtype and clonal type amongst serogroup-A strains

\begin{tabular}{|c|c|c|c|}
\hline $\begin{array}{l}\text { Class-1 pro- } \\
\text { tein variant }\end{array}$ & Subtype & $\begin{array}{c}\text { Number of reactive strains/ } \\
\text { number tested }\end{array}$ & Clone \\
\hline 2 & $\mathrm{P} 1 \cdot 1,16$ & $20 / 20$ & IV-1 \\
\hline 3 & P1.6 & $4 / 4$ & I-1 (ET9)*, II-2† \\
\hline 4 & P1.9 & $20 / 20$ & III- $1 \ddagger$, III- $2 \dagger$, III-3†, III-4† \\
\hline 5 & $\mathrm{P} 1 \cdot 2$ & $3 / 3$ & I-1 (ET6) \\
\hline 6 & $\mathrm{P} 1 \cdot 1,16$ & $3 / 3$ & II -3 \\
\hline 7 & P1.9 & $1 / 1$ & III-1 (ET36) \\
\hline
\end{tabular}

representative strains with the 12 subtyping McAbs, specific for Pl.1, Pl.1,16, Pl.16, P1.2, Pl.6, P1.9, and P1.15 (Abdillahi and Poolman, this review), resulted in the recognition of 4 different subtype antigens, P1.2, P1.6, Pl.9 and Pl.1,16 amongst 51 of the 100 serogroup-A strains. No examples were found in which strains assigned to one electrophoretic class-1 variant reacted with different subtyping McAbs (table IV). All 20 strains with class 1 variant 2 were of subtype Pl.1,16, whereas all 20 strains with variant 4 were of subtype P1.9. The four strains with variant 3 corresponded to subtype Pl.6, the sets of three strains with variants 5 and 6 were of subtype Pl.2 and Pl.1,16, respectively, and the single strain of variant 7 was of subtype P1.9 (table IV). Two pairs of class-1 variants (variant 2 and $6 ; \mathrm{Pl} .1,16$; and variants 4 and 7: P1.9) possessed the same subtype epitope.

All 49 strains which could not be subtyped either lacked a class-1 protein or possessed class-1 protein variant 1 . Variant 1 is the most common variant observed among serogroup-A strains and is particularly prevalent amongst old strains and amongst

\section{REFERENCES}

Abbot J D, Jones D M, Painter M J, Young S E J 1985 The epidemiology of meningococcal infection in England and Wales 1912-1983. Journal of Infection 11 :241-257.

Abdillahi $\mathrm{H}$, Crowe B A, Achtman M, Poolman J Two monoclonal antibodies which recognize the serotype 4 antigen of Neisseria meningitidis. European Journal of Clinical Microbiology, in press.

Abdillahi H, Poolman J T 1987 Typing of group B Neisseria meningitidis with monoclonal antibodies in the whole-cell ELISA. FEMS 48: 367-371.

Abdillahi H, Poolman J T, Hopman C T P, Zanen H C 1986 Sero- and subtyping of non-2a, non-2b and non-15 group $B$ Neisseria meningitidis. Antonie van Leeuwenhoek 52:242244.

Achtman $M$ et al. 1988 Purification and characterization of many of the clones of subgroups A-1 and A-II (Olyhoek et al., 1987). Consequently, the absence of a reagent capable of distinguishing this variant leaves a major gap in the subtyping scheme for serogroup A.

Because the association between the reaction of the subtyping McAbs and the electrophoretic variation was so strong and because the class-1 protein had been used as part of the clonal analysis, the subtyping results correlated with the clonal analysis. No correlations would have been observed if the clonal analysis had been solely based on the isoenzyme analysis of cytoplasmic enzymes.

We conclude that because serogroup-A strains are of uniform serotype (all serotype 4), serotyping is of little value for detailed epidemiological studies of this serogroup. In contrast, subtyping is capable of differentiating between serogroup-A strains and might be useful for epidemiological studies. Of the seven class- 1 variants resolved by outer-membraneprotein typing of serogroup-A strains, 6 reacted with subtyping McAbs exhibiting four different specificities.

eight class 5 outer membrane protein variants from a clone of Neisseria meningitidis serogroup A. Journal of Experimental Medicine, in press.

Achtman M, Pluschke G 1986 Clonal analysis of descent and virulence among selected Escherichia coli. Annual Review of Microbiology 40:185-210.

Barlow A K, Heckels J E, Clarke I N 1987 Molecular cloning and expression of Neisseria meningitidis class 1 outer membrane protein in Escherichia coli $\mathrm{K}-12$. Infection and Immunity 55: 2734-2740.

Barritt D S, Schwalbe R S, Klapper D G, Cannon J G 1987 Antigenic and structural differences among six proteins II expressed by a single strain of Neisseria gonorrhoeae. Infection and Immunity 55:2026-2031.

Beuvery E C, Miedema F, van Delft R, Haverkamp J 1983 Preparation and immunochemical characterization of meningococcal group $\mathrm{C}$ polysaccharide-tetanus toxoid conju- 
gates as a new generation of vaccines. Infection and Immunity 40: $39-45$.

Blackwell C C, Jonsdottir K, Mohammed J, Weir D M 1986 Non-secretion of blood group antigens: a genetic factor predisposing to infection by Neisseria meningitidis. Proceedings of the fifth international pathogenic neisseria conference $\bar{V}, \mathrm{p} 106$.

Blakebrough I S, Gilles H M 1980 The effect of rifampicin on meningococcal carriage in family contacts in northern Nigeria. Journal of Infection 2 : 137-143.

Blakebrough I S, Greenwood B M, Whittle H C, Bradley A K, Gilles H M 1982 The epidemiology of infections due to Neisseria meningitidis and Neisseria lactamica in a northern Nigerian community. Journal of Infectious Diseases 146:626-637.

Branham S E 1953 Serological relationships among meningococci. Bacteriological Reviews 17: 175-188.

Caugant D A et al. 1986a Multilocus genotypes determined by enzyme electrophoresis of Neisseria meningitidis isolated from patients with systemic disease and from healthy carriers. Journal of General Microbiology 132: 641-652.

Caugant D A et al. $1986 \mathrm{~b}$ Intercontinental spread of a genetically distinctive complex of clones of Neisseria meningitidis causing epidemic disease. Proceedings of the National Academy of Sciences of the USA 83:4927-4931.

Caugant D A, Mocca L F, Frasch C E, Froholm L O, Zollinger W D, Selander R K 1987 Genetic structure of Neisseria meningitidis populations in relation to serogroup, and outer membrane protein pattern. Journal of Bacteriology 169: 2871-2792.

Crowe B et al. 1986 Clonal analysis of Neisseria meningitidis serogroup A. Proceedings of the fifth international pathogenic neisseria conference I, p 14.

Dalhoff A 1985 Differences between bacteria grown in vitro and in vivo. Journal of Antimicrobial Chemotherapy 15 Suppl A: 175-195.

de Lemos R A, Haggerty R J 1969 Corticosteroids was an adjunct to treatment in bacterial meningitis: a controlled clinical trial. Pediatrics 44:30-34.

Densen P, Weiler J M, McLeod-Griffiss J, Hoffman L G 1987 Familial properdin deficiency and fatal meningococcaemia. New England Journal of Medicine 316:922-926.

De Wals P et al. 1981 Meningococcal disease in Belgium: secondary attack rate among household, day-care nursery, and pre-elementary school contacts. Journal of Infection 3 Suppl 1:53-61.

Edwards E A, Devine L F, Sengbusch C H, Ward H W 1977 Immunologic investigations of meningococcal disease: brevity of Group C acquisition prior to disease occurrence. Scandinavian Journal of Infectious Diseases 9: 105-110.

Eskola $\mathbf{J}$ et al. 1985 Antibody levels achieved in infants by course of Haemophilus influenzae type b polysaccharide-diphtheria toxoid conjugate vaccine. Lancet $1: 1184-1186$.

Fallon R J, Brown W M, Lore W 1984 Meningococcal infections in Scotland 1972-82. Journal of Hygiene 93: 167-180.

Ferguson J H, Chapman O D 1948 Fulminating meningococcic infections and the so-called Waterhouse-Friderichsen syndrome. American Journal of Pathology 24:763-796.

Filice G A, Hayes P S, Counts G W, Griffiss J M, Fraser D W 1985 Risk of group A meningococcal disease: bacterial interference and cross-reactive bacteria among mucosal flora. Journal of Clinical Microbiology 22: 152-156.

Finne J, Leinonen M, Makela P H 1983 Antigenic similarities between brain components and bacteria causing meningitis. Implications for vaccine development and pathogenesis. Lancet 2:355-357.

Fothergill L D, Wright J 1933 Influenzal meningitis: relation of age incidence to bactericidal power of blood against causal organism. Journal of Immunology 24:273-281.

Frasch C E 1977 Role of protein serotype antigens in protection against disease due to Neisseria meningitidis. Journal of Infectious Diseases 136 (Suppl):S84-S90.

Frasch C E, McNelis R M, Gotschlich E C 1976 Strain-specific variation in the protein and lipopolysaccharide composition of the group B meningococcal outer membrane. Journal of Bacteriology 127:973-981.

Frasch C E, Coetzee G, Zahradrik D M, Wang L K $1985 a$ New developments in meningococcal vaccines. In : Schoolnik G $K$ (ed) The pathogenic neisseriae. American Society for Microbiology, Washington, DC, pp 633-639.

Frasch C E, Zollinger W D, Poolman J T $1985 b$ Serotype antigens of Neisseria meningitidis and a proposed scheme for designation of serotypes. Reviews of Infectious Diseases 7:504-510.

Froholm L O et al. 1986 Preliminary results from a clinical trial with a meningococcal vaccine containing serotype $2 \mathrm{~b}$ and 15 antigens in complex with mixed A, C, K and W135 polysaccharides. Antonie van Leeuwenhoek 52:239-241.

Gerard P, Moriau M, Bachy A, Malvaux P, De Meyer R 1973 Meningococcal purpura : report of 19 patients treated with heparin. Pediatrics 82: 780-786.

Goldschneider I, Gotschlich E C, Artenstein M S 1969 Human immunity to the meningococcus. I. The role of humoral antibodies. Journal of Experimental Medicine 129:13071326.

Gotschlich E C, Austrian R, Cvjetanovic B, Robbins J B 1978 Prospects for the prevention of bacterial meningitis with polysaccharide vaccines. Bulletin of the WHO 56:509-518.

Gotschlich E C, Fraser B A, Nishimura O, Robbins J B, Liu T Y 1981 Lipid on capsular polysaccharides of gram-negative bacteria. Journal of Biological Chemistry 256:8915-8921.

Gotschlich E C, Goldschneider I, Artenstein M S 1969 Human immunity to the meningococcus IV. Immunogenicity of group $\mathrm{A}$ and gruup $\mathrm{C}$ meningococcal polysaccharides in human volunteers. Journal of Experimental Medicine 129:1367-1384.

Gotschlich E C, Liu T Y, Artenstein M S 1969 Human immunity to the meningococcus. III. Preparation and immunochemical properties of the group A, group B, and group C meningococcal polysaccharides. Journal of Experimental Medicine 129 : $1349-1365$.

Greenfield S, Sheehe P R, Feldman H A 1971 Meningococcal carriage in a population of "normal" families. Journal of Infectious Diseases 123:67-73.

Greenwood B M et al. 1987 Factors influencing susceptibility to meningococcal disease during an epidemic in The Gambia, West Africa. Journal of Infection 14:167-184.

Greenwood B M, Whittle H C, Bryceson A D M 1973 Allergic complications of meningococcal disease. II. Immunological investigations. British Medical Journal 269 : 737-740.

Greenwood B M, Whittle H C, Dominic-Rajkovic O 1971 Counter-current immunoelectrophoresis in the diagnosis of meningococcal infections. Lancet 2:519-521.

Griffiss J McL, Bertram M A 1977 Immunoepidemiology of meningococcal disease in military recruits. II. Blocking of serum bactericidal activity by circulating IgA early in the course of invasive disease. Journal of Infectious Diseases 136: 733-739.

Griffiss J McL 1982 Epidemic meningococcal disease : synthesis of a hypothetical immunoepidemiologic model. Reviews of Infectious Diseases 4:159-172.

Hall C J, Nelder C, Melville C A S 1985 Listeriosis. British Medical Journal $291: 608$.

Hankins W A, Gwaltney J M, Hendley J O, Farquar J D, 
Samuelson J S 1982 Clinical and serological evaluation of a meningococcal polysaccharide vaccine, Groups A, C, Y and W135. Proceedings of the Society for Experimental Biology and Medicine 169 : 54-57.

Heckels J E, Virji M 1985 Monoclonal antibodies against gonococcal pili: uses in the analysis of gonococcal immunochemistry and virulence. In: de Macario A J L, de Macario E C (eds) Monoclonal antibodies against bacteria, vol. I. Academic Press Inc, New York, pp 1-35.

Heist G D, Solis-Cohen S, Solis-Cohen M 1922 A study of the virulence of meningococci for man and of human susceptibility to meningococcic infection. Journal of Immunology 7:1.

Hobbs J R, Milner R D G, Watt P S 1967 Gamma-M deficiency predisposing to meningococcal septicaemia. British Medical Journal 4:583-586.

Jennings H J, Roy R, Michon P 1985 Determinant specificities of the groups $\mathrm{B}$ and $\mathrm{C}$ polysaccharides of Neisseria meningitidis. Journal of Immunology 134:2651-2657.

Jennings H J, Gamian A, Ashton F E 1987 N-propionylated group $B$ meningococcal polysaccharide mimics a unique epitope on group B meningococci. Journal of Experimental Medicine 165: 1207-1211.

Jones D M, Eldridge J, Sutcliffe E M 1986 Emergence of group B type 15 strains as a cause of meningococcal infection in England and Wales. Antonie van Leeuwenhoek 52:206-207.

Kaiser A B, Hennekens C H, Saslaw M S, Hayes P S, Bennett J V 1974 Seroepidemiology and chemoprophylaxis of disease due to sulfonamide-resistant Neisseria meningitidis in a civilian population. Journal of Infectious Diseases 130 : 217 223.

Käyhty H, Karanko V, Peltola H, Sarna S, Makela P H 1980 Serum antibodies to capsular polysaccharide vaccine of Group A Neisseria meningitidis followed for three years in infants and children. Journal of Infectious Diseases 142:861868.

Lapeyssonnie L 1963 La meningite cerebrospinale en Afrique. Bulletin of the WHO 28 Suppl:3-114.

Makela P H et al. 1977 Polysaccharide vaccines of group A Neisseria meningitidis and Haemophilus influenzae type b: a field trial in Finland. Journal of Infectious Diseases 136 Suppl:S43-S50.

Maniatis T, Fritsch E F, Sambrook J 1982 Molecular cloning: a laboratory manual. Cold Spring Harbor Laboratory, Cold Spring Harbor, NY.

Manios S G, Manakoudi F, Maniati E 1971 Fulminant meningococcemia. Heparin therapy and survival rate. Scandinavian Journal of Infectious Diseases 3:127-133.

Margaretten W, Csavassy I, McKay D G 1967 An electron microscope study of a case of meningococcemia in man. American Journal of Diseases of Children 114:268-277.

Meningococcal Disease Surveillance Group 1976 Meningococcal disease : secondary attack rate and chemoprophylaxis in the United States 1974. Journal of the American Medical Association 235: 261-265.

Mocca L F, Karpas A B, Wu L H, Frasch C E 1984 Functional activity of monoclonal antibodies against outer membrane surface antigens of Neisseria meningitidis. Proceedings of the 24th Interscience Conference on Antimicrobial Agents and Chemotherapy, p 295 (abstract).

Nicholson A, Lepow J H 1979 Host defence against Neisseria meningitidis requires a complement-dependent bactericidal activity. Science 205:298-299.

Olcen P, Kjellander J, Daniellsson D, Lindquist B L 1981 Epidemiology of Neisseria meningitidis prevalence and symptoms from the upper respiratory tract in family members to patients with meningococcal disease. Scandinavian Journal of Infectious Diseases 13:105-109.

Olyhoek T, Crowe B A, Achtman M 1985 Epidemiological analyses of the geographical distribution of Neisseria meningitidis group A. In : Schoolnik G K (ed)The pathogenic neisseriae. American Society for Microbiology, Washington DC, pp 530-535.

Olyhoek T, Crowe B A, Achtman M 1987 The clonal population structure of Neisseria meningitidis serogroup A isolated from epidemics and pandemics between 1915 and 1983. Reviews of Infectious Diseases 9:665-692.

Olyhoek T, Crowe B A, Wall B, Achtman M 1988 Comparison of clonal analysis and DNA restriction analysis for typing of Neisseria meningitidis. Microbial Pathogenesis 4:45-51.

Orchard R T, Cramb M, Parkins R A 1972 Chronic meningococcal septicaemia. Infection 209:338-339.

Peltola H 1983 Meningococcal disease: still with us. Reviews of Infectious Diseases 5:71-91.

Peltola $\mathrm{H}$ et al. 1977 Clinical efficacy of meningococcal group A vaccine in children three months to five years of age. New England Journal of Medicine 297:686-691.

Pinals R S, Ropes M W 1964 Meningococcal arthritis. Arthritis and Rheumatism 7:241-258.

Poolman J T, Buchanan T M 1983 Monoclonal antibodies against meningococcal outer membrane proteins. Medicine Tropical 43:139-142.

Poolman J T, de Marie S, Zanen H C 1980 Variability of lowmolecular-weight, heat-modifiable outer membrane proteins of Neisseria meningitidis. Infection and Immunity 30: $642-648$.

Poolman J T, Hopman C T P, Zanen H C $1985 a$ Colony variants of Neisseria meningitidis strain 2996 (B: 2b: P12): influence of class-5 outer membrane proteins and lipopolysaccharides. Journal of Medical Microbiology 19: 203-209.

Poolman J T, Lind I, Jonsdottir K, Forholm L O, Jones D M, Zanen H C 1986 Meningococcal serotypes and serogroup B disease in North-West Europe. Lancet 2:555-558.

Poolman J T, Wientjes F B, Hopman C T P, Zanen H C $1985 b$ Influence of the length of lipopolysaccharide molecules on the surface exposure of class 1 and 2 outer membrane proteins of Neisseria meningitidis 2996 (B: 2b: P1.2). In: Schoolnik G K (ed) The pathogenic neisseriae. American Society for Microbiology, Washington DC, pp 562-570.

Poolman J T, Zanen H C 1980 Antibody development after meningococcal disease as measured by gel-immuno-radioassay (GIRA). In: Daniellsson D, Normark S (eds) Genetics and immunobiology of pathogenic neisseria. Umea University Press, pp 107-115.

Poolman J T et al. 1987 Comparison of meningococcal outer membrane protein vaccines, solubilized with detergent or C polysaccharide. Antonie van Leeuwenhoek 53:413-419.

Ross S C, Densen P 1984 Complement deficiency states and infection; epidemiology, pathogenesis and consequences of neisserial and other infections in an immune deficiency. Medicine 63:243-273.

Ross S C, Rosenthal P J, Berberich H M, Densen P 1987 Killing of Neisseria meningitidis by human neutrophils: implications for normal and complement-deficient individuals. Journal of Infectious Diseases 155 : 1266-1275.

Saukkonen K, Abdillahi H, Poolman J T, Leinonen M 1987 Protective efficacy of monoclonal antibodies to class 1 and 3 outer membrane proteins of Neisseria meningitidis B: 15: $\mathrm{Pl} .16$ in infant rat infection model. New prospects for vaccine development. Microbial Pathogenesis 3:261-268.

Selander R K, Caugant D A, Ochman H, Musser J M, Gilmour M N, Whittman T S 1986 Methods of multilocus enzyme electrophoresis for bacterial population genetics and sys- 
tematics. Applied and Environmental Microbiology 51 : 873884.

Selander R K, Musser J M, Caugant D A, Gilmour M A, Whittman T S 1987 Population genetics of pathogenic bacteria. Microbial Pathogenesis 3: 1-7.

Severin W P J 1972 Latex agglutination in the diagnosis of meningococcal infection. Journal of Clinical Pathology 25: 1079-1082.

Slawig B 1986 Antigen-spezifitat von Serum-Antikorpern in Bezug auf die Zelloberflache von Neisseria meningitidis der Serogruppe A. Freie Universitat, Fachbereich Biologie, Berlin, pp 1-114.

Stern A, Meyer T F 1987 Common mechanism controlling phase and antigenic variation in pathogenic neisseriae. Molecular Microbiology $1: 5-12$.

Swanson J, King G 1978 Neisseria gonorrhoeae granulocyte interactions. In: Brooks C F (ed) Immunobiology of Neisseria gonorrhoeae. American Society for Microbiology, Washington DC, pp 221-226.

Tinsley C R, Heckels J E 1986 Variation in the expression of pili and outer membrane protein by Neisseria meningitidis during the course of meningococcal infection. Journal of General Microbiology 132: 2483-2490.

Tsai C-M, Frasch C E, Mocca L F 1981 Five structural classes of major outer membrane proteins in Neisseria meningitidis. Journal of Bacteriology 146:69-78.

Van Putten J M P, Linders M T, Weel J F L, Poolman J T 1987 Differential expression of Fe-repressible and growth-ratesensitive proteins in Neisseria meningitidis and Neisseria gonorrhoeae. Antonie van Leeuwenhoek 53:557-564.

Virji M, Heckels J E 1983 Antigenic cross-reactivity of Neisseria pili: investigations with type- and species-specific monoclonal antibodies. Journal of General Microbiology 129: 2761-2768.

Virji M, Heckels J E, Watt P J 1983 Monoclonal antibodies to gonococcal pili: studies on antigenic determinants on pili from variants of strain P9. Journal of General Microbiology 129: 1965-1973.

Virji M, Zak K, Heckels J E 1985 Use of monoclonal antibodies to detect common protein antigens present in outer membranes of Neisseria species. In: Schoolnik G K (ed) The pathogenic neisseriae. American Society for Microbiology, Washington DC, pp 276-280.

Vieusseaux M 1805 Memoire sur le maladie qui a regne a Geneve au printemps de 1805. Journal de Medicine, Chirurgie et Pharmacie II: $163-165$.

Wedege E, Michaelsen T E 1987 Human immunoglobin G subclass immune response to outer membrane antigens in meningococcal group B vaccine. Journal of Clinical Microbiology 25 : 1349-1353.

Weichselbaum A 1887 Uber die aeriologie der akuten meningitis cerebrospinalis. Fortschritte der Medecin 5:573-575.

Wenzel R P, Davies J A, Mitzel J R, Beam W E 1973 Non usefulness of meningococcal carriage-rates. Lancet 2:205.

Whittle H C et al. 1973 Allergic complications of meningococcal disease I-clinical aspects. British Medical Journal 269 : 733 737.

Wyle F A et al. 1972 Immunologic response of man to group B meningococcal polysaccharide vaccines. Journal of Infectious Diseases 126:514-522.

Zollinger W D, Mandrell R E 1980 Type-specific antigens of group A Neisseria meningitidis : lipopolysaccharide and heatmodifiable outer-membrane proteins. Infection and Immunity 28:451-458.

Zollinger W D, Mandrell R E, Altieri P, Berman S, Lowenthal J, Artenstein M S 1978 Safety and immunogenicity of a Neisseria meningitidis type 2 protein vaccine in animals and humans. Journal of Infectious Diseases 137:728-739.

Zollinger W D, Mandrell R E, Griffiss J M, Altieri P, Berman S 1979 Complex of meningococcal group $B$ polysaccharide and type 2 outer membrane protein immunogenic in man. Journal of Clinical Investigation 63:836-848.

Zollinger W D, Moran E E, Connelly H, Mandrell R E, Brant R 1984 Monoclonal antibodies to serotype 2 and serotype 15 outer membrane proteins of Neisseria meningitidis and their use in serotyping. Infection and Immunity 46:260-266.

Zollinger W D, Pennington C L, Artenstein M S 1974 Human antibody response to three meningococcal outer membrane antigens: comparison by specific haemagglutination assay. Infection and Immunity 10:975-984. 